\title{
Data on Adiponectin from 2010 to 2020: Therapeutic Target and Prognostic Factor for Liver Diseases?
}

\author{
Misaq Heydari ${ }^{1}\left(\mathbb{D}\right.$, María Eugenia Cornide-Petronio ${ }^{1}\left(\mathbb{D}\right.$, Mónica $^{B}$. Jiménez-Castro ${ }^{1, *(D)}$ and \\ Carmen Peralta $1,2, *$ (D)
}

1 Institut d'Investigacions Biomèdiques August Pi I Sunyer (IDIBAPS), 08036 Barcelona, Spain; misaqheydari@gmail.com (M.H.); cornide@clinic.cat (M.E.C.-P.)

2 Centro de Investigación Biomédica en Red de Enfermedades Hepáticas y Digestivas (CIBERehd), 08036 Barcelona, Spain

* Correspondence: monicabjimenez@hotmail.com; (M.B.J.-C.); cperalta@clinic.cat (C.P.); Tel.: +34-932275400 (M.B.J.-C.); +34-932275400 (C.P.)

Received: 19 June 2020; Accepted: 22 July 2020; Published: 23 July 2020

\begin{abstract}
The review describes the role of adiponectin in liver diseases in the presence and absence of surgery reported in the literature in the last ten years. The most updated therapeutic strategies based on the regulation of adiponectin including pharmacological and surgical interventions and adiponectin knockout rodents, as well as some of the scientific controversies in this field, are described. Whether adiponectin could be a potential therapeutic target for the treatment of liver diseases and patients submitted to hepatic resection or liver transplantation are discussed. Furthermore, preclinical and clinical data on the mechanism of action of adiponectin in different liver diseases (nonalcoholic fatty disease, alcoholic liver disease, nonalcoholic steatohepatitis, liver cirrhosis and hepatocellular carcinoma) in the absence or presence of surgery are evaluated in order to establish potential targets that might be useful for the treatment of liver disease as well as in the practice of liver surgery associated with the hepatic resections of tumors and liver transplantation.
\end{abstract}

Keywords: adiponectin; ischemia-reperfusion; liver transplantation; partial hepatectomy; NAFLD; NASH

\section{Introduction}

Herein, we review the preclinical and clinical studies reported over the last ten years that investigate the mechanisms of action of adiponectin in liver diseases, in both the presence and absence of surgery. Potential targets and pharmacological strategies aimed at regulating adiponectin in liver diseases are also discussed. Our reasons for this research are threefold. Firstly, there is a need for useful pharmacological strategies to treat nonalcoholic fatty liver disease (NAFLD)/nonalcoholic steatohepatitis (NASH) and avoid progression to cirrhosis and cancer. Secondly, given the prevalence of NAFLD in both society at large and liver transplantation (LT) donation (30\% in cadaveric and $20 \%$ in living donors), NAFLD pathology has become a major focus of scientific and clinical research [1,2]. Specifically in LT, the presence of NAFLD in the donor liver increases the risk of ischemia/reperfusion (I/R) injury and liver regeneration failure compared with non-steatotic ones. In fact, the use of steatotic livers is associated with an increased risk of primary nonfunction or dysfunction. In addition, many donated livers are not suitable for transplantation because of excess steatosis, which exacerbates the critical shortage of donor livers [3]. Thus, I/R injury associated with LT and hepatic resection of tumors, mostly in different liver diseases, is an unsolved problem in clinical practice. Finally, the increasing number of studies of the role of adiponectin in liver diseases (mainly in the absence of liver surgery) reported in the last 10 years, suggests that this adipocytokine could form the basis of useful strategies 
for the treatment of NAFLD/NASH and its progression as well as in the clinical practice of liver resections and transplantation.

\subsection{Characteristics and Isoforms of Adiponectin in Liver Diseases}

Adiponectin is a $28 \mathrm{kDa}$ protein hormone including 274 amino acids encoded by the AdipoQ gene. Adiponectin exists in plasma as three distinct oligomeric complexes: the homotrimer (low-molecular weight, LMW mass, $\sim 70 \mathrm{kDa}$ ), the hexamer (middle-molecular weight, MMW mass, $\sim 140 \mathrm{kDa}$ ) and 12-18 protomer (high-molecular weight, HMW mass, $>300 \mathrm{kDa}$ ) $[4,5]$.

The total and distribution of all three adiponectin isoforms (LMW, HMW and MMW) are decreased in NAFLD patients without any surgical intervention [6]. HMW adiponectin suppresses growth factor-induced hepatic stellate cell (HSC) proliferation and may be closely associated with lipid metabolism [7]. Experimental data suggest that HMW adiponectin is the most potent isoform for alleviation of fatty liver disease in high fat diet-induced obese mice [8], whereas Bianchi et al. concluded that there is no significant contribution of adiponectin isoform distribution to the progression of liver diseases [6]. In surgical conditions such as normothermic hepatic ischemia associated with hepatic resection, HMW is the predominant isoform of adiponectin in steatotic livers [9]. No data have been reported on the levels of the different adiponectin isoforms in other I/R conditions, such as hepatic resection under vascular occlusion or LT.

\subsection{Source of Adiponectin in Liver Diseases}

Different studies of liver diseases related to NAFLD/NASH without any surgical intervention have suggested that adipose tissue is a major site of endogenous adiponectin production [10-15]. However, this situation might be different when patients with NAFLD/NASH require liver surgery. In fact, data obtained from steatotic livers subjected to warm hepatic ischemia without resection as well as from non-steatotic livers undergoing $6 \mathrm{~h}$ of cold ischemia without brain death indicate that adiponectin is generated by the liver $[9,16]$. Indeed, steatotic livers have been shown to generate adiponectin in an isolated perfused liver model without the presence of either circulation or adipose tissue. This is in line with clinical studies reporting that the expression of hepatic adiponectin in patients with NAFLD undergoing partial hepatectomy is derived from hepatocytes themselves rather than from migration of peripheral adipose tissue [17]. Further studies are necessary to elucidate the role of adipose tissue and liver in the changes in adiponectin levels in LT with extended criteria donors (for instance, liver grafts from cardiac arrest donors) as well as in living-related LT.

\subsection{Adiponectin Receptors in Liver Diseases}

Adiponectin enhances the binding of APPL1 (an adaptor protein containing a pleckstrin homology domain, a phosphotyrosine binding domain and a leucine zipper motif) to the two adiponectin receptors (adipoR1 and adipoR2). These interactions are essential for subsequent adiponectin actions [18,19]. However, there is controversy concerning the expression of the adiponectin receptors in animal models of obesity; similarly, hepatic adiponectin receptor mRNAs in NAFLD/NASH patients are found unchanged, decreased or even increased [20-24]. Intensive research efforts are needed to evaluate the expression and role of the different adiponectin receptors in hepatic resections and LT. Nevertheless, given the NAFLD/NASH results, in our view, the role of adiponectin depends on the different isoforms and receptors involved as well as on the type of liver and surgical conditions (as discussed in Sections 5 and 6 of the current review). If that were the case, specific strategies should be adopted to regulate the effects of adiponectin depending on the type of liver as well as the surgical conditions.

\section{Adiponectin Effects on Hepatic Damage and Regenerative Failure Associated with Hepatic I/R}

As mentioned above, the data suggest that the role of adiponectin depends on the surgical conditions and type of liver. Thus, adiponectin is injurious to steatotic livers submitted to $60 \mathrm{~min}$ of normothermic ischemia [9]. However, beneficial effects of adiponectin on regeneration are reported 
in steatotic livers undergoing partial hepatectomy under vascular occlusion. Moreover, adiponectin plays a minor role in non-steatotic liver grafts subjected to $6 \mathrm{~h}$ of cold ischemia, whereas it protects in the presence of steatosis [16]. Similarly, to these surgical findings, different results have been reported for the mechanisms of action of adiponectin. It is a positive regulator of resistin in LT of steatotic grafts. Thus, adenosine monophosphate-activated protein kinase (AMPK) activation by the drug, aminoimidazole-4-carboxamide ribonucleoside (AICAR) and surgical ischemic preconditioning increased adiponectin, which in turn upregulated resistin in steatotic liver grafts without brain death. The upregulation of phosphoinositide 3-kinase (PI3K)/protein kinase B (Akt) induced by resistin protected steatotic livers against damage [16]. Meanwhile, data on chronic feeding of high-fat diets to rodents indicate a negative correlation between adiponectin and resistin (decreased adiponectin and increased resistin plasma levels) [25], whereas, in NAFLD patients, no correlation between adiponectin and resistin was reported [26,27]. Furthermore, in preclinical studies without brain death, ischemic preconditioning increased adiponectin levels in liver grafts submitted to $6 \mathrm{~h}$ of cold ischemia, but not in LT from brain-dead donors, which most closely resemble the surgical conditions occurring in clinical practice [28]. Furthermore, adiponectin is beneficial for liver regeneration in hepatic resection under vascular occlusion. In fact, results indicate that adiponectin $-/-$ mice exhibit delayed liver regeneration following partial hepatectomy $[29,30]$. These benefits of adiponectin might be mediated by signal transducer and activator of transcription-3 (STAT3) signaling and progression through the cell cycle. In addition, adiponectin negatively regulates the fibroblast growth factor 2 (FGF2) response and other growth factors derived from stellate cells [31,32] (Figure 1).

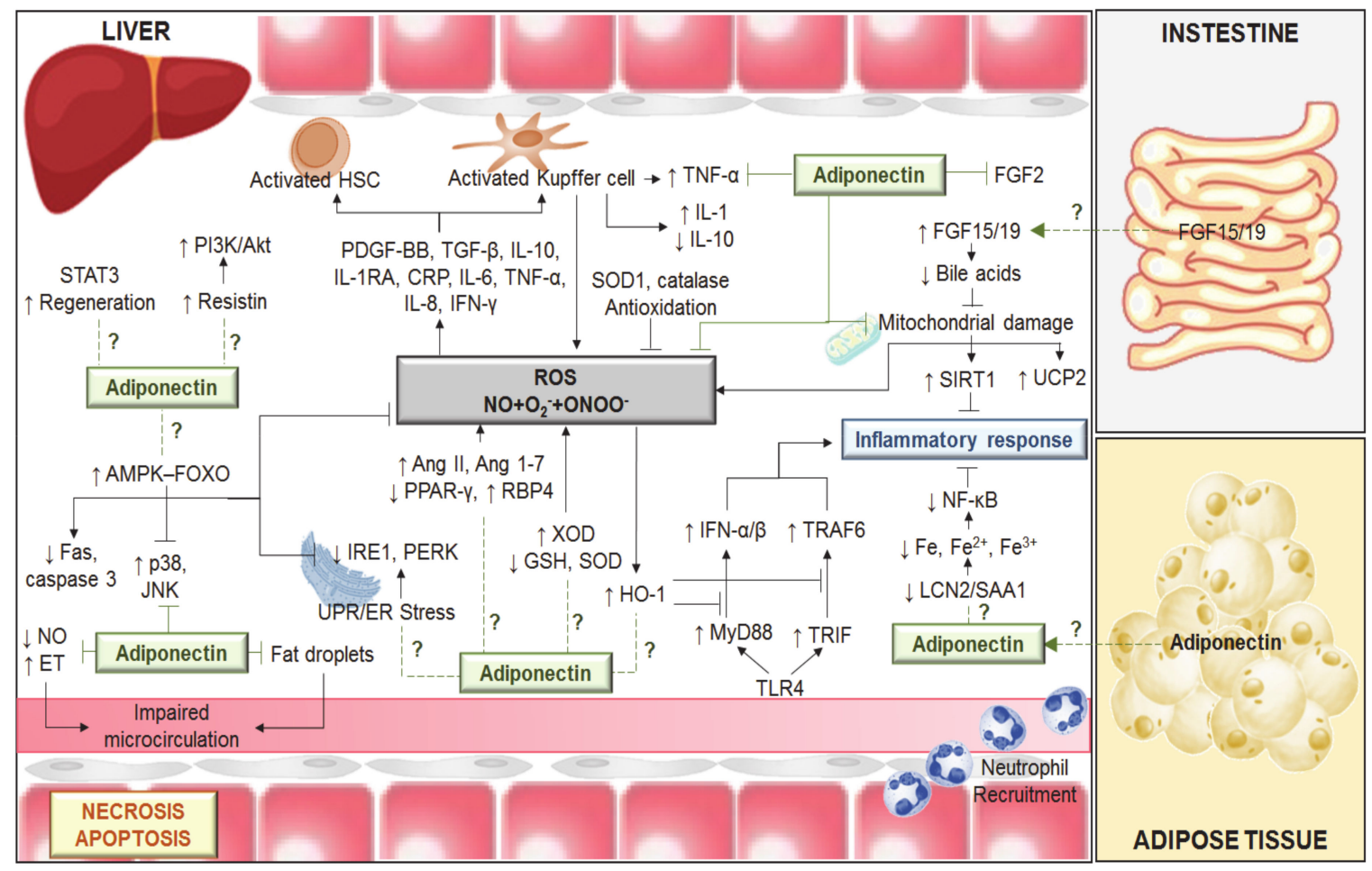

Figure 1. Mechanisms involved in the effects of adiponectin in different liver diseases including hepatic $\mathrm{I} / \mathrm{R}$. Ischemia-induced energy deficiency results in the failure of active transmembrane transport and consequently in endothelial cell (EC) and Kupffer cell (KC) swelling. KC activation results in reactive 
oxygen species (ROS), tumor necrosis factor alpha (TNF- $\alpha$ ) and interleukin (IL)-1 release. In addition, ROS (derived from xanthine/xanthine oxidase (X/XOD) and mitochondria), the low levels of antioxidants (superoxide dismutase (SOD), glutathione (GSH) and catalase) and the alterations in the levels of angiotensin (Ang) II, Ang 1-7, peroxisome proliferator-activated receptor-gamma (PPAR- $\gamma$ ), retinol binding protein 4 (RBP4), tumor growth factor beta (TGF- $\beta$ ), IL-1, among others, induce activation of hepatic stellate cells (HSC) and KCs, which in turn induces the release of TNF- $\alpha$ and IL-1 and promotes low IL-10 levels. The imbalance between nitric oxide (NO) and endothelin (ET) production contributes to the narrowing of sinusoidal lumen. The endoplasmic reticulum (ER) stress involves the activation of ER proteins, namely inositol-requiring enzyme 1 (IRE1), protein kinase-like endoplasmic reticulum kinase (PERK) and activating transcription factor 6 (ATF6). ER stress induction contributes to inflammatory response, which might be regulated by adiponectin. This adipocytokine activates the adenosine monophosphate-activated protein kinase (AMPK) $\neq$ forkhead box protein $\mathrm{O}(\mathrm{FOXO})$ signaling axis, showing anti-apoptosis actions, because of decreasing the expression of Fas-associated death domain (Fas) and caspase 3. Adiponectin prevents the activation of c-Jun N-terminal kinase (JNK) and p38 mitogen-activated protein kinase (p38). The anti-inflammatory actions of adiponectin are mediated by a regulation of toll-like receptor 4 (TLR4) signaling via myeloid differentiation primary response gene 88 (MyD88) and TIR-domain-containing adapter-inducing interferon- $\beta$ (TRIF) pathways; the mitochondrial dysfunctions and the lipocalin-2/serum amyloid A1 (LCN2/SAA1)-iron metabolism. Indeed, adiponectin upregulated the uncoupling protein 2 (UCP2), catalase, and SOD1. Adiponectin might play a crucial role regulating the farsenoid-X receptor (FXR)-fibroblast growth factor 15 (FGF15) pathway in the gut-liver axis. Adiponectin might activate signal transducer and activator of transcription-3 (STAT3) and resistin signaling as well as negatively regulate the fibroblast growth factor 2 (FGF2) response. Akt, protein kinase B; CRP, C-reactive protein; Fe, Iron; HO-1, heme oxygenase-1; IFN, interferon; NF- $\mathrm{B}$, nuclear factor kappa-light-chain-enhancer of activated $\mathrm{B}$ cells; $\mathrm{O}_{2}$, superoxide; ONOO-, peroxynitrite; PDGF-BB, platelet-derived growth factor-BB; PI3K, phosphoinositide 3-kinase; SIRT1, sirtuin 1; TRAF6, TNF receptor-associated factor 6; UPR: unfolded protein response. $\uparrow:$ increase; $\downarrow$ : decrease.

\section{Anti-Steatotic Effects of Adiponectin in Liver Diseases}

In obesity, it has been reported that adiponectin protects liver from steatosis and inflammation: it increases the capacity of insulin to suppress glucose production [33]. A diet deficient in choline and L-amino acid induces more severe hepatic steatosis in adiponectin deficient mice than in wild-type animals [34]. In the same way, adenoviral expression of adiponectin ameliorates lipid deposition in the liver. Sterol regulatory element-binding protein 1c (SREBP-1c) is a central regulator of fatty acid synthesis, and it is suppressed by adiponectin in hepatocytes and in the liver of $\mathrm{db} / \mathrm{db}$ mice [35]. In addition, through the downregulation of lipogenic transcription factor, SREBP-1c, adiponectin prevents hepatic lipogenesis [36]. The induction of AMPK by adiponectin might explain its effects on anabolic and catabolic pathways. It is known that AMPK switches on adenosine triphosphate (ATP)-producing catabolic pathways (fatty acid oxidation and glycolysis) and switches off ATP-consuming anabolic pathways (lipogenesis) [37]. Thus, when adiponectin activates AMPK, glucose utilization and fatty-acid oxidation in the liver are elevated. Suppression of SREBP-1c by adiponectin is mediated through AdipoR1/liver kinase B1 (LKB1)—an upstream kinase of the AMPK pathway [35]. In addition, AMPK phosphorylates acetyl-CoA carboxylase (ACC), and this is subsequently associated with higher activity of carnitine palmitoyl- transferase 1 (CPT-1), a rate limiting enzyme in fatty acid oxidation [37]. In addition, it is reported that adiponectin stimulates peroxisome proliferator-activated receptor alpha (PPAR $\alpha$ ) activity, which enhances fat oxidation, reduces lipid synthesis and prevents accumulation of fatty infiltration [38]. All of this has been reported in experimental obesity models without any liver surgery.

It should be also noted that adiponectin reduces chronic inflammation in target organs including vasculature, lung and heart, thereby leading to protection against various obesity-related disorders [39]. However, the experiments were performed in vitro so further studies are required to clarify this issue. It has also been demonstrated that serum has lower adiponectin levels, before and after transplantation. 
However, if such changes are associated with cardiovascular events in long-term follow-up of liver transplant recipients remain to be elucidated [40]. It is also important to clarify this because systemic inflammation following the release into circulation of different mediators from the liver has been reported in surgical conditions of hepatic I/R [41,42].

The effects of adiponectin in steatotic livers undergoing surgery and on various obesity-related disorders should not be ignored. Indeed, the different signaling pathways such as AMPK and PPAR $\alpha$ involved in the anti-steatotic effects of adiponectin also play a role in protecting steatotic livers undergoing I/R against damage (Figure 2).

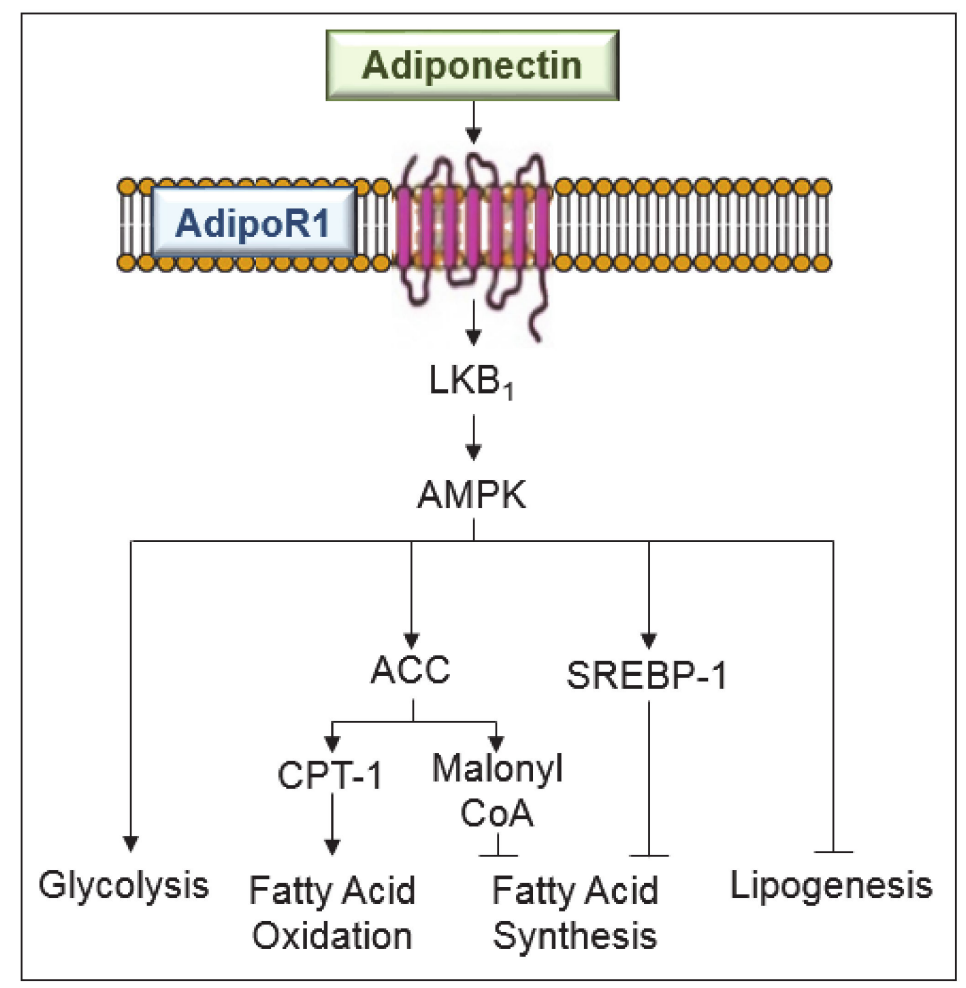

Figure 2. Signaling pathways involved in the anti-steatotic effects of adiponectin in liver diseases. Adiponectin, mediated by adenosine monophosphate-activated protein kinase (AMPK) exerts the following effects: suppresses sterol regulatory element-binding protein-1c (SREBP-1c), a central regulator of fatty acid synthesis and an inhibitor of lipogenesis; increases the glucose utilization and fatty-acid oxidation; increases the activity of carnitine palmitoyl-transferase-1 (CPT-1), a rate limiting enzyme in fatty acid oxidation; and regulates malonyl CoA for fatty acid synthesis inhibition. ACC, acetyl-CoA carboxylase; LKB, liver kinase B1.

\section{Relationship between Adiponectin and Leptin in Fibrogenesis}

Hepatic fibrosis is the last prevalent pathway prior to cirrhosis and eventually requires LT. Among the different adipocytokines (retinol binding protein 4 (RBP4), resistin, apelin, chemerin, vaspin, etc.), adiponectin is one chiefly involved in hepatic fibrosis [43]. In patients with liver cirrhosis, circulating adiponectin is elevated, independent of disease etiology, age or body mass index [44]. This might be explained by its effect on the inflammatory response [45], a reduction in biliary excretion [46] or an imbalance between adiponectin production and hepatic excretion [47]. Both leptin and adiponectin play key roles in obesity-related disorders and are associated with the pathogenesis of NAFLD [48]. In NAFLD patients, concentrations of adiponectin are decreased whereas leptin levels are increased, indicating an imbalance of adipocytokines, which might promote the progression of this liver disease [48]. Indeed, in vitro studies based mainly on culture-activated HSCs suggest that hepatic fibrosis and its resolution are controlled by adiponectin and leptin. 
Adiponectin has strong-antifibrotic features whereas leptin acts as a profibrogenic molecule. This is because adiponectin prevents leptin signal transduction [43]. In fact, adiponectin (through protein tyrosine phosphatase 1B (PTP1B)) prevents the leptin-mediated activation of the janus kinase 2 (Jak2)/STAT3 pathway. By inducing suppressors of cytokine signaling 3 (SOCS3), adiponectin also suppresses leptin activity. Moreover, adiponectin provokes HSC apoptosis and suppresses HSC proliferation and $\alpha$ collagen biosynthesis. In addition, adiponectin-mediated prevention of leptin signaling leads to downregulation of tissue inhibitor of metalloproteinase 1 (TIMP-1) transcription and TIMP-1 activity, while adiponectin increases the capacity of matrix metalloproteinase 1 (MMP-1) to degrade fibrillar collagen in cellular matrix. It further prevents the activity of focal adhesion kinase (FAK) and disrupts the formation of mature focal adhesions (FA) [43]. All of this is scientifically and clinically relevant, but several concerns should be taken into account: it all needs to be confirmed in an experimental model of NASH that simulates the characteristics of this pathology as soon as possible in clinical practice.

In a choline-deficient mouse NASH model, low levels of adiponectin have been reported [49], although their relevance remains unclear. Adiponectin increased apoptosis of hepatocellular carcinoma (HCC) cells via activation of caspase-3, and increased phosphorylation of c-Jun N-terminal kinase (JNK) [50]. Data obtained from cell cultures and animal models suggest that adiponectin inhibits leptin-induced proliferation of HCC via blocking downstream pathways including STAT-3, AKT and mammalian target of rapamycin (m-TOR) [51]. Adiponectin also provokes the suppression of liver tumor growth and metastasis in mice by inhibiting angiogenesis, and it shows chemoprotective and hepatoprotective functions by blocking sulfatase 2 [52,53]. Although basic mechanistic studies indicate that leptin acts to promote HCC proliferation, migration and invasion [54], clinical observation showed that higher leptin expression was associated with increased HCC survival [55]. Similarly, although experimental studies indicated that adiponectin increased HCC apoptosis and prevented liver tumor growth and metastasis, increased adiponectin has also been associated with both favorable prognosis [56] and reduced HCC survival [57]. Further studies are required to resolve this issue. Nevertheless, several concerns should be considered. Experimental models are needed that simulate the progression of NAFLD to HCC in conditions similar to those in clinical practice, and dependence of the roles of adiponectin and leptin on sex must be considered. Indeed, data analysis by gender shows considerably higher levels of adiponectin and leptin in control group females than in males [58]. Lower levels of adiponectin in males may account for their higher prevalence of liver cancer. Testosterone activates JNK in human and mouse adipocytes, and genetic deletion of JNK1 in mouse adipose tissue leads to higher levels of adiponectin and protection against HCC. Increased AMPK and mitogen-activated protein kinase (p38 $\alpha$ ) activation levels were detected in females, associated with the higher levels of adiponectin in female mice [59] (Figure 3). 


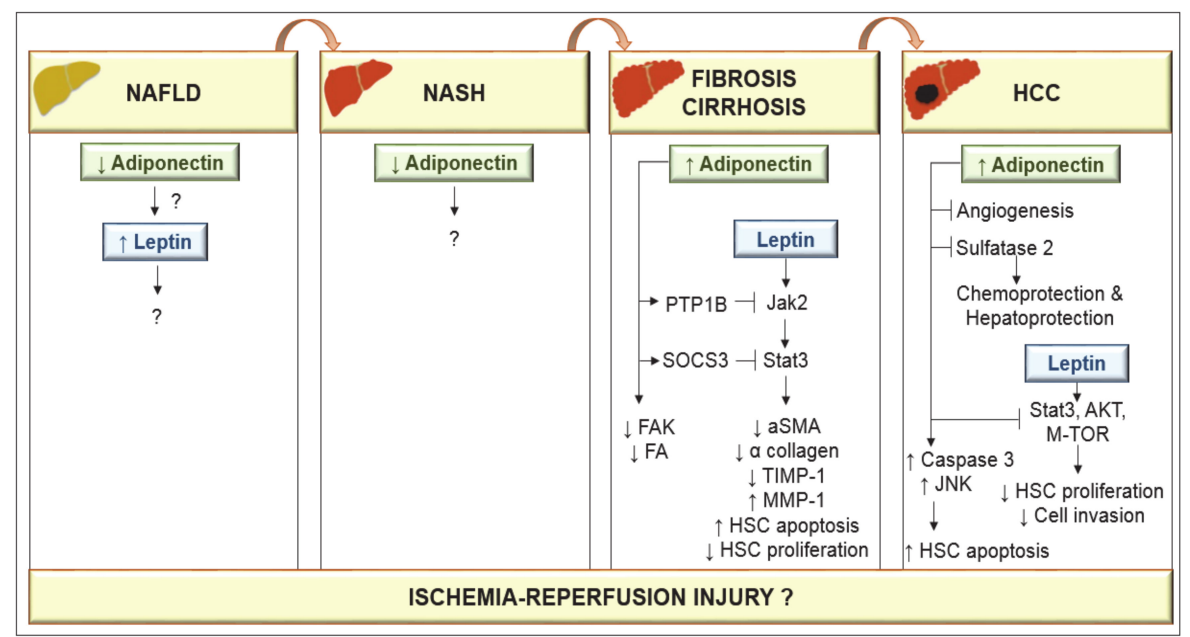

Figure 3. Adiponectin and leptin in the progression of nonalcoholic fatty liver disease (NAFLD) to hepatocellular carcinoma (HCC). Low adiponectin levels have been observed in either NAFLD or nonalcoholic steatohepatitis (NASH) conditions. However, the effects on leptin as well as the mechanisms of action of adiponectin are unknown. In cirrhosis, circulating adiponectin is elevated. Adiponectin through protein tyrosine phosphatase 1B (PTP1B) prevents the leptin-mediated activation of the janus kinase 2 (Jak2)/signal transducer and activator of transcription-3 (STAT3) pathway through suppressors of cytokine signaling 3 (SOCS3) and the activity of focal adhesion kinase (FAK) and focal adhesion (FA). By inducing SOCS3, adiponectin suppresses leptin activity. Adiponectin can provoke hepatic stellate cells (HSC) apoptosis and leads to the loss of $\alpha$-smooth muscle actin ( $\alpha$-SMA) proteins in HSCs and suppresses HSC proliferation and $\alpha$ collagen biosynthesis. Adiponectin-mediated prevention of leptin signaling downregulates tissue inhibitor of metalloproteinase 1 (TIMP-1) activity and increases matrix metalloproteinase 1 (MMP-1) to degrade fibrillar collagen in matrix. Adiponectin increases apoptosis of HCC cells via activation of caspase-3, and c-Jun N-terminal kinase (JNK). Adiponectin inhibits leptin-induced proliferation of HCC via blockade of STAT-3, protein kinase B (AKT) and mammalian target of rapamycin (m-TOR) and shows hepatoprotective functions by blocking angiogenesis and sulfatase 2 .

\section{Pharmacological Strategies Regulating the Action of Adiponectin on Hepatic Damage and Regenerative Failure Associated with Hepatic I/R}

In an experimental model of LT, the administration of adiponectin reduced hepatic injury and increased regeneration in both steatotic and non-steatotic grafts submitted to $6 \mathrm{~h}$ of cold ischemia [16]. Adiponectin increased resistin, which in turn resulted in PI3K/Akt over-expression [16]. In an experimental model of partial hepatectomy using adiponectin $-/-$ mice, the authors reported that adiponectin accelerated cell cycle progression relative to wild-type mice. Such benefits were mediated by STAT3 signaling and progression through the cell cycle [31].

Pharmacological strategies aimed at modulating the actions of adiponectin are ineffective in non-steatotic livers from Zucker rats undergoing $60 \mathrm{~min}$ of warm ischemia, as well as in surgical procedures requiring liver regeneration such as partial hepatectomy with $I / R$ [9]. However, treatment with adiponectin protected non-steatotic livers of Wistar rats subjected to $60 \mathrm{~min}$ warm $\mathrm{I} / \mathrm{R}$ by reducing the inflammatory response [C-C motif chemokine ligand 2 (CCL-2), C-X-C motif chemokine ligand 10 (CXCL-10), intercellular cell adhesion molecule (ICAM)-1 and cytokines such as interleukin (IL)-1 $\beta$, IL-6 and tumor necrosis factor $\alpha$ (TNF- $\alpha$ )] and hepatocyte apoptosis. Such effects of adiponectin are mediated via AMPK/endothelial nitric oxide synthase (eNOS) [60]. These differences in the effects of adiponectin in studies of warm I/R $[9,60]$ might be explained, at least partially, by the use of different species or different treatments: siRNA of adiponectin versus recombinant adiponectin. The studies using adiponectin siRNA and recombinant adiponectin $[9,60]$ assessed the role of endogenous and exogenous adiponectin, respectively. Thus, similar to what occurs for nitric oxide (NO), the roles of endogenous and exogenous adiponectin might be different. The AMPK signaling pathway is also involved in the 
actions of adiponectin in an experimental model of chronic intermittent liver hypoxia. Thus, adiponectin supplementation induced AMPK activation which reduced the reactive oxygen species (ROS) generation from endoplasmic reticulum stress, and the activation of the three apoptotic pathways [61]. The benefits of adiponectin against inflammation and apoptosis have also been reported in non-steatotic LT without brain death [62]. The mechanism involved in this protection includes anti-inflammatory effects (evidenced by decreased production of neutrophils and inflammatory cytokines, e.g., TNF- $\alpha$ and nuclear factor kappa-light-chain-enhancer of activated B cells (NF-kB) activation) and anti-apoptosis effects, due to decreased expression of the Fas-associated death domain (Fas) and caspase 3 [62].

Regarding the reported effects of adiponectin on liver regeneration, treatment with the anti-diabetic drug rosiglitazone, which is thought to act by elevating serum adiponectin, inhibits liver mass recovery [63]. Nonetheless, in our view, the effects of rosiglitazone on liver regeneration might be explained by mechanisms other than adiponectin upregulation. The results based on adiponectin -/- mice in an experimental model of partial hepatectomy indicate the benefits of adiponectin for liver regeneration [31]. However, these results based on knockout animals might be different from those observed with adiponectin treatment, due to the different effects of endogenous and exogenous adiponectin. It is still unknown whether strategies aimed at increasing adiponectin levels might be useful in NAFLD patients undergoing hepatectomy to improve regenerative failure. Indeed, the over-expression of hepatic adiponectin in patients with NAFLD undergoing hepatectomy is elicited by excessive stimulation of the proinflammatory cytokine, TNF- $\alpha$, which exerts negative effects on liver regeneration. The relevance of such high adiponectin levels remains to be clarified [17]. Moreover, it has been reported that hepatic accumulation of systemically derived fat from adipose tissue in non-steatotic livers undergoing partial hepatectomy promotes liver regeneration [64]. Interestingly, recent data suggest an association between intrahepatic fat content and adiponectin levels in patients undergoing liver resection [65]. In preclinical studies based on NAFLD undergoing partial hepatectomy, the expression of PPAR $\alpha$ is tightly regulated by AdipoR2 axis, whereas the expression of AMPK is a downstream molecule of AdipoR1 axis [17]. Thus, the action of adiponectin depends on the type of receptor as well as on the type of liver and surgical conditions (Table 1).

Table 1. Effect of strategies that regulate adiponectin action in liver surgery in studies from 2010 to 2020.

\begin{tabular}{|c|c|c|c|c|}
\hline Treatment & Isoform and Receptor & $\begin{array}{c}\text { Type of Liver and } \\
\text { Specie }\end{array}$ & Surgical Condition & Effect and Signaling Pathways \\
\hline $\begin{array}{c}\text { Adiponectin } \\
\text { recombinant } \\
\text { (Rat Acrp30) [16] }\end{array}$ & Not reported & $\begin{array}{c}\text { Steatotic and } \\
\text { non-steatotic livers from } \\
\text { Zucker rats }\end{array}$ & $\begin{array}{c}\text { LT } \\
\text { Ischemia: } 6 \mathrm{~h} \\
\text { Reperfusion: } 4 \mathrm{~h}\end{array}$ & $\begin{array}{c}\downarrow \text { Hepatic injury and mortality } \\
\quad \uparrow \text { Ki-67 } \\
\text { Adiponectin- } \uparrow \text { Resistin- } \uparrow \text { PI3K/Akt }\end{array}$ \\
\hline Dietary model [17] & $\begin{array}{c}\text { Not reported; } \\
\text { AdipoR1 and AdipoR2 }\end{array}$ & $\begin{array}{l}\text { Steatotic livers from } \\
\text { Sprague-Dawley MCD } \\
\text { or HFD rat }\end{array}$ & Partial $(70 \%)$ hepatectomy & $\begin{array}{c}\downarrow \text { AdipoR1 and AdipoR2 } \\
\uparrow \text { Hepatic adiponectin, TNF- } \alpha \text {, AMPK } \\
\text { AdipoR1- } \uparrow \text { AMPK in MCD and HFD } \\
\text { AdipoR2- } \downarrow \text { PPAR } \alpha \text { in MCD }\end{array}$ \\
\hline Adiponectin (-/-) [31] & Not reported & $\begin{array}{l}\text { Livers from } \\
\text { B6.129-Adipoq } \\
\text { knockout mice }\end{array}$ & Partial hepatectomy & $\begin{array}{c}\downarrow \text { Regeneration by controlling cell cycle } \\
\text { progression, cytokine signaling and growth } \\
\text { factor bioavailability } \\
\text { Adiponectin- } \uparrow \text { STAT3 }\end{array}$ \\
\hline $\begin{array}{l}\text { Adiponectin } \\
\text { recombinant [60] }\end{array}$ & Not reported & Livers from Wistar rats & $\begin{array}{l}\text { Partial warm ischemia } \\
\text { Ischemia: } 60 \mathrm{~min} \\
\text { Reperfusion: } 6,24 \mathrm{~h}\end{array}$ & $\begin{array}{c}\downarrow \downarrow \text { Hepatic injury, inflammatory cell infiltration, } \\
\text { IL-1 } \beta, \text { IL-6, TNF- } \alpha, \text { CCL2, CXCL10, ICAM1, } \\
\text { apoptosis } \\
\text { Adiponectin- } \uparrow \text { AMPK/eNOS }\end{array}$ \\
\hline $\begin{array}{l}\text { Adiponectin } \\
\text { recombinant and } \\
\text { supplementation } \\
\text { (Rat gAcrp30) [61] }\end{array}$ & Not reported & Livers from Wistar rats & $\begin{array}{l}\text { Chronic intermittent } \\
\text { hypoxia events for } 8 \mathrm{~h} \text { per } \\
\text { day for } 4 \text { months }\end{array}$ & $\begin{array}{c}\downarrow \text { Hepatic injury, ROS production, fasting blood } \\
\text { glucose, triglycerides } \\
\text { Adiponectin- } \uparrow \text { AMPK }\end{array}$ \\
\hline $\begin{array}{c}\text { Adiponectin } \\
\text { recombinant } \\
\text { (Rat gAcrp30) [62] }\end{array}$ & Not reported & $\begin{array}{l}\text { Livers from } \\
\text { Sprague-Dawley rats }\end{array}$ & $\begin{array}{c}\text { LT } \\
\text { Ischemia: } 30 \mathrm{~min} \\
\text { Reperfusion: } 3,6,12,24 \mathrm{~h}\end{array}$ & $\begin{array}{c}\downarrow \text { Bile duct injury and apoptosis, Fas, caspase } 3, \\
\text { TNF- } \alpha, \text { NF- } \kappa \text { B activation, MPO, IL- } 6 \\
\text { Adiponectin- } \downarrow \text { NF- } \kappa B\end{array}$ \\
\hline \multicolumn{5}{|c|}{$\begin{array}{l}\uparrow \text {, increase; } \downarrow \text {, decrease; Acrp30, Adiponectin; AdipoR1/R2, adiponectin receptor type } 1 / 2 ; \text { And } / \text {, adiponectin } \\
\text { knockout; Akt, protein kinase B; AMPK, adenosine monophosphate-activated protein kinase; CCL2, C-C motif } \\
\text { chemokine ligand 2; CXCL10, C-X-C motif chemokine ligand 10; eNOS, endothelial nitric oxide synthase; } \\
\text { Fas, Fas-associated death domain; gAcrp30, globular adiponectin; h, hours; HFD, high fat diet; ICAM1, } \\
\text { intercellular cell adhesion molecule 1; IL, interleukin; Ki-67, antigen Ki-67, a marker of proliferation; LT, liver } \\
\text { transplantation; MCD, methionine-choline deficiency; min, minutes; MPO, myeloperoxidase; NF-kB, nuclear factor } \\
\text { kappa-light-chain-enhancer of activated B cells; PPAR } \alpha \text {, peroxisome proliferator-activated receptor alpha; PI3K, } \\
\text { phosphoinositide 3-kinase; ROS, reactive oxygen species; STAT3, signal transduce and activator of transcription 3; } \\
\text { TNF- } \alpha \text {, tumor necrosis factor alpha. The signaling pathway is described in italics. }\end{array}$} \\
\hline
\end{tabular}




\section{Pharmacological Strategies to Regulate Adiponectin Action in Liver Diseases and the Absence of Hepatic I/R}

In a study using rats fed ethanol, the anti-inflammatory effects of adiponectin were mediated by regulation of toll-like receptor 4 (TLR4) signaling via the myeloid differentiation primary response gene 88 (MyD88) and TIR-domain-containing adapter-inducing interferon- $\beta$ (TRIF) pathways [66] (Table 2). In AdipoR1- and AdipoR2-knockout obese mice, treatment with adiponectin decreased the levels of mitochondrial lipid peroxidation since it upregulated uncoupling protein 2 (UCP2), catalase and superoxide dismutase 1 (SOD1) in the liver [67].

It has also been suggested that one explanation for the absence of a NAFLD phenotype might be upregulation of adiponectin, which activates the AMPK-forkhead box protein O (FOXO) signaling axis and probably overrides detrimental oxidative stress and JNK signaling [68] (Figure 1).

Decreased serum levels of adiponectin and decreased gene expression of ileum fibroblast growth factor 15 (FGF15) have been reported in chronic ethanol fed mice, whereas elevated levels of circulating adiponectin and FGF15 protected against inflammation and liver damage [69,70]. These results suggest that the adiponectin-FGF15/19 axis participates in the regulation of ethanol-induced inflammation in mouse liver $[69,70]$. Serum levels of adiponectin are inversely associated with hepatic bile acid synthesis, serum bile acid levels and hepatocellular injury in NAFLD patients [71]. Additionally, adiponectin directly regulates genes related to bile acid homeostasis such as cholesterol 7 alpha-hydroxylase (Cyp7a1) [71]. Given that both FGF15/19 and adiponectin can regulate bile acid homeostasis, this could partially explain the protective effect of adiponectin-FGF15/19 signaling against ethanol- induced liver injury [72] (Figure 1). These observations might be of relevance for liver surgery given the dysregulation of the farsenoid-X receptor (FXR)-FGF15 pathway in the gut-liver axis in different liver diseases. Whether adiponectin exerts its action directly on the liver or on the intestine (the source of FGF15 generated by ileal FXR) remains to be elucidated. This is scientifically and clinically relevant to the search for the best route of adiponectin administration. It is well known that, under brain death conditions, the gut and hepatic blood flow is reduced and this makes drug delivery to the appropriate site of action and at the optimal concentration difficult. In addition, a recent study by our group of steatotic and non-steatotic LT from brain-dead donors indicates the critical role of the gut-liver axis and the relevance of FGF15/19 in the pathogenesis of hepatic I/R injury and regenerative failure [73].

Pharmacological intervention aimed at elevating adiponectin levels have been reported as promising for the treatment and progression of NAFLD [74]. Thus, one study in patients with NASH shows that increases of adiponectin produced by pioglitazone are related to improvements in steatosis, inflammation and fibrosis, thereby confirming the crucial role of adiponectin in this pathology [75]. Clinical and experimental studies of NASH show that PPAR agonists or vitamin E are potential therapies in NAFLD/NASH since they upregulate adiponectin levels $[76,77]$. Treatment with PPAR $\gamma$, such as rosiglitazone, increases the levels and sensitivity of adiponectin receptors [78]. Hume et al. indicated that after 16 weeks of supplementing overweight children with prebiotic fiber, there was a significant increase in adiponectin, while leptin levels did not change [79]. Supplementation with the probiotic Lactobacillus gasseri (SBT 2055) reduced abdominal visceral fat and increased serum adiponectin in obese people [80]. Thus, to date, pharmacological evidence suggests that metabolic improvements induced by anti-obesity drugs (orlistat, sibutramine and rimonabant), insulin sensitizers (metformin and thiazolidinediones) and endocannabinoid receptor antagonists could be attributed, at least in part, to the induction of high plasma levels of adiponectin [81-84]. The results show an increase in plasma adiponectin, ghrelin and leptin levels, as well as insulin sensitivity, four weeks after melatonin administration in a cohort of patients with NASH [82]. Those authors hypothesized that melatonin could improve the key pathogenetic factors associated with NAFLD, namely insulin resistance and hypoadiponectinemia, and in turn confer protection against inflammation and oxidative stress $[82,85,86]$ (Table 2). 
Table 2. Effect of strategies that regulate adiponectin in liver diseases in the absence of surgery in studies from 2010 to 2020 .

\begin{tabular}{|c|c|c|c|c|}
\hline Treatment & Isoform and Receptor & $\begin{array}{c}\text { Type of Liver and } \\
\text { Specie }\end{array}$ & $\begin{array}{l}\text { Surgical } \\
\text { Condition }\end{array}$ & Effect and Signaling Pathways \\
\hline $\begin{array}{c}\text { Adiponectin } \\
\text { recombinant } \\
\text { (Human gAcrp30) [66] }\end{array}$ & $\begin{array}{l}\text { HMW and Adipo R1 and } \\
\text { AdipoR2 }\end{array}$ & $\begin{array}{c}\text { KC and RAW } 264.7 \\
\text { macrophages from } \\
\text { Wistar rats with chronic } \\
\text { ethanol-feeding }\end{array}$ & Cell culture & $\begin{array}{c}\downarrow \text { TLR4 (/MyD88), IFN- } \beta, \text { CXCL10 } \\
\text { Adiponectin- }-\downarrow \text { TLR4 }\end{array}$ \\
\hline CHIP (-/-) [68] & $\begin{array}{l}\text { Not reported; } \\
\text { AdipoR1 and AdipoR2 }\end{array}$ & $\begin{array}{l}\text { Livers from CHIP } \\
\text { knockout mice }\end{array}$ & Cell culture & $\begin{array}{c}\downarrow \text { Oxidative stress and JNK } \\
\uparrow \text { Adiponectin, AdipoR1, AdipoR2, AMPK and } \\
\text { FOXO } \\
\text { Adiponectin- } \uparrow \text { AMPK-FOXO }\end{array}$ \\
\hline $\begin{array}{l}\text { mLipin-1 (-/-) (Human } \\
\text { gAcrp30) [69] }\end{array}$ & $\begin{array}{l}\text { HMW; AdipoR1 and } \\
\text { AdipoR2 }\end{array}$ & $\begin{array}{l}\text { Livers from mLipin-1 } \\
\text { knockout mice with } \\
\text { chronic ethanol-feeding }\end{array}$ & NA & $\begin{array}{c}\downarrow \text { Hepatic injury, inflammation, NF-kB, } \\
\uparrow \text { Adiponectin, AdipoR1, AdipoR2 and FGF15 } \\
\text { Adiponectin- } \uparrow \text { FGF15 signaling }\end{array}$ \\
\hline mNT (-/-) [70] & Not reported & $\begin{array}{l}\text { mNT knockout mice } \\
\text { with chronic } \\
\text { ethanol-feeding }\end{array}$ & NA & $\begin{array}{c}\downarrow \text { Hepatic injury, NF-kB, oxidative stress } \\
\uparrow \text { Adiponectin, FGF15, Sirt1 } \\
\text { Adiponectin- } \uparrow \text { FGF15 signaling }\end{array}$ \\
\hline Pioglitazone [75] & Not reported & NASH patients & NA & $\begin{array}{c}\downarrow \text { Hepatic steatosis and necroinflammation } \\
\uparrow \text { Adiponectin } \\
\text { Adiponectin- } \downarrow N F-\kappa B / / N K\end{array}$ \\
\hline Rosiglitazone [78] & $\begin{array}{l}\text { HMW; AdipoR1 and } \\
\text { AdipoR2 }\end{array}$ & $\begin{array}{l}\text { Livers from C57BL/6J } \\
\text { mice with } \\
\text { ethanol-feeding }\end{array}$ & NA & $\begin{array}{c}\downarrow \text { Hepatic injury, steatosis, lipogenesis } \\
\uparrow \text { Adiponectin and hepatic AdipoR1/R2 } \\
\text { Adiponectin- } \uparrow \text { SIRT1-AMPK }\end{array}$ \\
\hline $\begin{array}{l}\text { Prebiotic fiber } \\
\text { supplementation [79] }\end{array}$ & Not reported & $\begin{array}{l}\text { Children patients with } \\
\text { overweight and obese }\end{array}$ & NA & $\begin{array}{l}\uparrow \text { Adiponectin and ghrelin } \\
\text { Not reported adiponectin signaling pathway }\end{array}$ \\
\hline $\begin{array}{l}\text { Probiotic Lactobacillus } \\
\text { gasseri (SBT2055) [80] }\end{array}$ & $\begin{array}{l}\text { HMW, MMW, LMW and } \\
\text { not reported receptor }\end{array}$ & Obese patients & NA & $\begin{array}{c}\downarrow \text { Abdominal visceral fat } \\
\uparrow \text { HMW in obese and control group } \\
\uparrow \text { MMW only in control group } \\
\text { Not reported adiponectin signaling pathway }\end{array}$ \\
\hline Melatonin [82] & Not reported & NASH patients & NA & $\begin{array}{l}\downarrow \text { HOMA-IR } \\
\uparrow \text { Adiponectin, leptin and ghrelin } \\
\text { Not reported adiponectin signaling pathway }\end{array}$ \\
\hline Orlistat [84] & Not reported & NAFLD patients & NA & $\begin{array}{l}\downarrow \text { Fatty infiltration, periostin, TNF- } \alpha \\
\quad \uparrow \text { Adiponectin } \\
\text { Not reported adiponectin signaling pathway }\end{array}$ \\
\hline
\end{tabular}

$\uparrow$, increase; $\downarrow$, decrease; AdipoR1/R2, adiponectin receptor type 1/2; AMPK, adenosine monophosphate-activated protein kinase; CXCL10, C-X-C motif chemokine ligand 10; CHIP, C-terminus of Hsc70-interacting protein; FGF15, fibroblast growth factor 15; gAcrp30, globular adiponectin; FOXO, forkhead box protein O; HMW, high molecular weight; HOMA-IR, homeostatic model assessment for insulin resistance; IFN- $\beta$, interferon beta; JNK, c-Jun N-terminal kinase; KC, Kupffer cells; LMW, low molecular weight; mLipin-1, myeloid cell-specific lipin-1; MMW, middle molecular weight; mNT, mitoNEET; MyD88, myeloid differentiation primary response gene 88; NA, not apply; NAFLD, nonalcoholic fatty liver disease; NASH, nonalcoholic steatohepatitis; NF- $\mathrm{KB}$, nuclear factor kappa-light-chain-enhancer of activated B cells; Sirt1, sirtuin-1; TLR4, toll-like receptor 4; TNF- $\alpha$, tumor necrosis factor alpha. The signaling pathway is described in italics.

In our view, the interpretation of these results of the treatments that increase adiponectin levels should be taken into account because of the lack of specificity in the modulation of adiponectin action. The difficulties producing functionally active recombinant adiponectin are well known, as the molecule is subjected to extensive post-translational modifications and is secreted in complex multimers $[87,88]$. For this reason, in our opinion, adiponectin analogs, such as osmotin (a ligand for the yeast homolog of the adiponectin receptor) [89], might provide a therapeutic alternative. Another way is indirect upregulation of innate adiponectin expression and secretion through administration of appropriated therapeutic agents $[87,88]$.

Despite the benefits of drugs regulating adiponectin action mentioned above, some of them have shown potential side effects; for instance, weight gain and fat redistribution from the central area to the lower body and also hepatotoxicity are reported following pioglitazone treatment [90-94]. One study suggested that PPAR $\gamma$ activity in liver of mice leads to storage of lipid in the liver $[95,96]$. Different data in rodent models showed that rosiglitazone exacerbates hepatic steatosis [95-97]. Thiazolidinediones causes increased risk of bladder cancer, weight gain, edema, cardiovascular complications and bone loss [95]. There are several concerns about using vitamin E, such as increase in the relative risk of hemorrhagic stroke and prostate cancer [98-100]. One study on ob/ob mice indicated that rosiglitazone dramatically increases liver steatosis [78,97]. Furthermore, it has been reported that weight and fat gain, water retention, cardiovascular toxicity, early signs of hypertrophic cardiomyopathy, hepatosteatosis 
and hepatotoxicity are side effects of rosiglitazone treatment [101,102]. In addition to mild unpleasant gastrointestinal side effects that are commonly reported with orlistat use, increased risk of serious hepatic events is another concern of using this medication [103]. Common side effects of sibutramine include nausea, headache and increased risk of myocardial infarction and stroke [104]. The results of one meta-analysis show that treatment with rimonabant is associated with psychiatric and neurologic adverse events [105]. Therefore, more studies are needed before future application of these drugs in the clinical practice.

\section{Adiponectin as a Prognostic Factor in Liver Diseases}

In rodents with obesity induced by a high fat diet and in ob/ob mice, adiponectin levels in plasma were decreased [106-108]. In patients with NAFLD, low levels of adiponectin are closely associated with the degree of hepatic steatosis, necroinflammation and fibrosis $[109,110]$. Adiponectin plays an important role in the progression of simple liver steatosis to NASH [111-114]. Thus, different studies suggest the use of serum adiponectin levels as a diagnostic measure of the necro-inflammatory grade and fibrosis in NAFLD, as well as it being a potential NAFLD therapeutic target [115]. However, multivariate regression analysis identifies decreased adiponectin as an independent predictor of liver steatosis in obese individuals [116]. This is in line with several large prospective studies of NAFLD patients, which investigated the role of serum adiponectin as a prognostic factor in NAFLD [117,118]. Thus, in a meta-analysis published in 2018 of 122 studies, the importance of adiponectin levels in the diagnosis of NAFLD was limited [119]. Consequently, it has been reported that more sensitive and specific diagnostic methods are needed to diagnose NAFLD [120]. In our view, and in line with reports by other authors [103], the combination of different cytokines might be the best prognostic factor in liver diseases. Indeed, lower serum adiponectin and resistin concentrations and higher serum RBP4 concentrations were evident in children with advanced liver steatosis. In addition, the same authors indicated that adiponectin, resistin and RBP4 levels could be useful for differentiating patients with advanced liver steatosis from those with mild steatosis [121]. There is a reverse association between serum adiponectin and the presence of NAFLD, which is positively associated with visfatin, IL- 6 and TNF- $\alpha$. It has been reported that an increased probability of NASH would be followed by decreased levels of serum adiponectin and elevated levels of circulating visfatin, IL- 8 and TNF- $\alpha$ [115]. This is in line with studies indicating that the evaluation of adiponectin level by itself is insufficient for a diagnosis of NAFLD/NASH and their progression $[115,121]$. Shimada et al. reported that $90 \%$ of patients with early-stage NASH could be predicted by a combined evaluation of serum levels of adiponectin, homeostatic model assessment for insulin resistance (HOMA-IR) score and serum type IV collagen 7S level [122]. Likewise, in patients with cirrhosis, higher levels of adiponectin are associated with liver dysfunction and worse prognosis [123-126]. Moreover, it has been reported that adiponectin is an independent predictor of overall survival in HCC patients $[127,128]$.

All these observations indicate the importance of future research to elucidate whether adiponectin or a combination of adipocytokines in serum is a useful diagnostic marker in NAFLD/NASH as well as in hepatic resections and LT. Indeed, to the best of our knowledge, no studies have evaluated in detail the potential association between serum adiponectin levels and the hepatic steatosis, damage and regenerative failure associated with liver surgery (Table 3). 
Table 3. Association between adiponectin levels and pathological characteristics in different liver disease.

\begin{tabular}{|c|c|c|c|}
\hline Disease & Subjects (Etiology) & Adiponectin Levels & Effect \\
\hline $\begin{array}{l}\text { Alcoholic liver } \\
\text { disease (ALD) [58] }\end{array}$ & 147 patients & $\begin{array}{l}\text { 18.69 ALD } \\
6.38 \text { control }\end{array}$ & $\begin{array}{l}\uparrow \text { Adiponectin (Acrp30) associated with } \\
\text { advanced liver dysfunction and ALD } \\
\text { complications }\end{array}$ \\
\hline NAFLD [112] & 63 patients & $\begin{array}{l}4.26 \pm 2.71 \mu \mathrm{g} / \mathrm{mL} \text { NAFLD } \\
5.85 \pm 3.74 \mu \mathrm{g} / \mathrm{mL} \text { controls }\end{array}$ & $\begin{array}{l}\downarrow \text { Three isoforms of adiponectin. HMW } \\
\text { and MMW adiponectin involved in the } \\
\text { pathogenesis and progression of NAFLD }\end{array}$ \\
\hline NAFLD [113] & $\begin{array}{c}315 \text { patients } \\
\text { (129 mild, } 145 \text { moderate, } 41 \\
\text { severe) }\end{array}$ & $\begin{array}{c}13.6 \pm 3.3 \mu \mathrm{g} / \mathrm{mL} \text { mild } \\
12.4 \pm 3.7 \mu \mathrm{g} / \mathrm{mL} \text { moderate } \\
11.6 \pm 3.5 \mu \mathrm{g} / \mathrm{mL} \text { severe } \\
\end{array}$ & $\begin{array}{l}\uparrow \text { adiponectin correlated with a decreased } \\
\text { risk of developing type } 2 \text { diabetes }\end{array}$ \\
\hline NAFLD [114] & $\begin{array}{l}232 \text { patients } \\
\text { (45 cirrhosis, } 71 \text { viral hepatitis, } 64 \\
\text { NAFLD, } 52 \text { others) }\end{array}$ & $\begin{array}{c}18.6 \pm 14.5 \mu \mathrm{g} / \mathrm{mL} \text { cirrhosis } \\
8.4 \pm 6.1 \mu \mathrm{g} / \mathrm{mL} \text { without cirrhosis } \\
4.8 \pm 3.5 \mu \mathrm{g} / \mathrm{mL} \text { NAFLD } \\
9.1 \mu \mathrm{g} / \mathrm{mL} \text { controls }\end{array}$ & $\begin{array}{l}\text { Adiponectin correlate positively with } \\
\text { markers of hepatic fibrosis. } \\
\downarrow \text { Adiponectin in NAFLD and } \uparrow \text { in } \\
\text { cirrhosis }\end{array}$ \\
\hline NAFLD [115] & 70 patients & $\begin{array}{c}8.14 \pm 2.91 \mathrm{mg} / \mathrm{L} \text { NAFLD } \\
13.63 \pm 2.88 \mathrm{mg} / \mathrm{L} \text { controls }\end{array}$ & $\begin{array}{l}\downarrow \text { Adiponectin and } \uparrow \text { visfatin, IL- } 6 \text {, TNF- } \alpha \\
\text { associated with increased NAFLD }\end{array}$ \\
\hline NAFLD [117] & 52 patients & $3.9(2.5-6.2) \mu \mathrm{g} / \mathrm{mL}$ & $\begin{array}{l}\text { Adiponectin, TNF- } \alpha \text {, IL- } 6 \text {, leptin were not } \\
\text { associated with disease progression }\end{array}$ \\
\hline NAFLD [118] & 147 patients & $\begin{array}{c}9.6 \pm 4.1 \mu \mathrm{g} / \mathrm{mL} \text { NAFLD } \\
14.0 \pm 10.1 \mu \mathrm{g} / \mathrm{mL} \text { without NAFLD }\end{array}$ & $\downarrow$ Adiponectin associated with NAFLD \\
\hline NAFLD [120] & $\begin{array}{l}71 \text { children patients } \\
\text { (37 with NAFLD, } 14 \text { with NASH, } \\
20 \text { without NAFLD) }\end{array}$ & $\begin{array}{c}13.15 \pm 5.33 \mathrm{ng} / \mathrm{mL} \text { NAFLD } \\
12.64 \pm 5.54 \mathrm{ng} / \mathrm{mL} \text { NASH }\end{array}$ & $\begin{array}{l}\text { Adiponectin levels were similar in } \\
\text { patients with and without NAFLD. } \\
\uparrow \text { AdipoR2 in NAFLD and is a } \\
\text { noninvasive marker for diagnosis }\end{array}$ \\
\hline NAFLD [121] & $\begin{array}{c}148 \text { children patients ( } 63 \text { steatosis, } \\
12 \text { steatosis and } \uparrow \text { ALT, } 85 \text { without } \\
\text { steatosis) }\end{array}$ & $\begin{array}{c}2.7 \pm 0.7 \mu \mathrm{g} / \mathrm{mL} \text { steatosis } \\
2.5 \pm 0.4 \mu \mathrm{g} / \mathrm{mL} \text { NAFLD } \\
4.7 \pm 1.1 \mu \mathrm{g} / \mathrm{mL} \text { without steatosis }\end{array}$ & $\begin{array}{l}\downarrow \text { Adiponectin were negatively correlated } \\
\text { with ALT activity }\end{array}$ \\
\hline Cirrhosis [123] & 122 patients & $\begin{array}{l}21.59 \mu \mathrm{g} / \mathrm{mL} \text { cirrhosis } \\
12.52 \mu \mathrm{g} / \mathrm{mL} \text { controls }\end{array}$ & $\begin{array}{l}\uparrow \text { Adiponectin associated with } \uparrow \text { liver } \\
\text { dysfunction and worse prognosis }\end{array}$ \\
\hline Cirrhosis [124] & $\begin{array}{l}70 \text { patients } \\
\text { (40 cirrhosis, } 30 \text { cirrhosis and } \\
\text { cholestasis) }\end{array}$ & $\begin{array}{c}15.1 \pm 12.1 \mu \mathrm{g} / \mathrm{mL} \text { cirrhosis } \\
21.28 \pm 10.2 \mu \mathrm{g} / \mathrm{mL} \text { cirrhosis with } \\
\text { cholestasis } \\
4.7 \pm 4.48 \mu \mathrm{g} / \mathrm{mL} \text { controls }\end{array}$ & $\begin{array}{l}\uparrow \text { Adiponectin shows correlation with } \\
\text { degree of hepatocellular injury and } \\
\text { cholestasis; but not with parameters of } \\
\text { body composition or metabolism }\end{array}$ \\
\hline Cirrhosis [125] & 140 patients & $13.050 \mathrm{ng} / \mathrm{mL}$ & $\begin{array}{l}\text { Adiponectin was an independent } \\
\text { predictor of overall survival in HCC } \\
\text { patients }\end{array}$ \\
\hline Cirrhosis [126] & $\begin{array}{l}40 \text { patients with non-diabetic } \\
\text { alcoholic cirrhosis }\end{array}$ & $10.23 \mu \mathrm{g} / \mathrm{mL}$ & $\begin{array}{l}\uparrow \text { Adiponectin associated with shorter } \\
\text { survival in the univariate analysis but not } \\
\text { in the multivariate analysis }\end{array}$ \\
\hline Cirrhosis [127] & $\begin{array}{l}248 \text { patients with compensated } \\
\text { viral hepatitis } C \text { cirrhosis }\end{array}$ & $16.5 \pm 15.3 \mu \mathrm{g} / \mathrm{mL}$ cirrhosis & $\begin{array}{l}\text { Adiponectin was not related to HCC, } \\
\text { liver-related death or LT during follow-up }\end{array}$ \\
\hline Cirrhosis [128] & $\begin{array}{l}90 \text { patients with hepatitis } \\
\text { C-related liver cirrhosis } \\
\text { (61 with, } 29 \text { without) }\end{array}$ & $\begin{array}{c}5.213 \pm 3.840 \mu \mathrm{g} / \mathrm{mL} \text { cirrhosis with HCC } \\
9.000 \pm 2.234 \mu \mathrm{g} / \mathrm{mL} \text { cirrhosis without HCC }\end{array}$ & $\begin{array}{l}\downarrow \text { Adiponectin levels associated with } \\
\text { HCC; a biomarker of HCC }\end{array}$ \\
\hline
\end{tabular}

Note: $\uparrow$, increase; $\downarrow$, decrease; Acrp30, Adiponectin; AdipoR2, adiponectin receptor type 2; ALD, alcoholic liver disease; ALT, alanine aminotransferase; HCC, hepatocellular carcinoma; HMW, high molecular weight; IL, interleukin; LT, liver transplantation; MMW, middle molecular weight; NAFLD, nonalcoholic fatty liver disease; $\mathrm{NASH}$, nonalcoholic steatohepatitis; TNF- $\alpha$, tumor necrosis factor alpha.

Note: $\uparrow$, increase; $\downarrow$, decrease; Acrp30, Adiponectin; AdipoR2, adiponectin receptor type 2; ALD, alcoholic liver disease; ALT, alanine aminotransferase; HCC, hepatocellular carcinoma; HMW, high molecular weight; IL, interleukin; LT, liver transplantation; MMW, middle molecular weight; NAFLD, nonalcoholic fatty liver disease; NASH, nonalcoholic steatohepatitis; TNF- $\alpha$, tumor necrosis factor alpha.

\section{Conclusions and Perspectives}

The benefits of adiponectin in terms of obesity, inflammation and regeneration may not apply in all I/R-dependent hepatic surgical scenarios. The role of adiponectin and the signaling pathways involved in its action depend on the surgical conditions, donor and type of liver subjected to surgery. All of this reveals the difficulties in establishing potential targets for the application of adiponectin in clinical practice: if the same pharmacological strategies are applied indiscriminately to steatotic and non-steatotic livers, the effects may be very different.

Specific drugs that regulate the action of adiponectin, research into the structure of adiponectin receptors, identification of molecules downstream of AdipoR1/2 and strategies to enhance adiponectin receptor activity constitute promising approaches to the treatment of NAFLD/NASH [129]. The potential 
applications of drugs that specifically regulate adiponectin are numerous in liver surgery, which in turn can lead to increasing the number of organs suitable for LT, and may provide a novel therapeutic approach to hepatic resection of tumors. Meanwhile, it is difficult to produce functionally active recombinant adiponectin because the molecule is subjected to extensive posttranslational modifications and secreted in complex multimers. In addition, each type of adiponectin isoform performs different actions, activating specific signaling pathways, and the role of adiponectin also depends on its receptors. Moreover, the types of adiponectin isoforms and receptors involved in each liver disease should be assessed in detail since the studies reported in the literature are very limited. All the related findings need to be considered if our aim is the application of drugs that regulate the actions of adiponectin in clinical practice related to liver diseases.

Further studies are necessary to elucidate the role of adipose tissue in the changes of adiponectin levels in different liver diseases. Currently, the results reported in the literature are contradictory and there is a lack of appropriate experimental designs including for instance the evaluation of adiponectin in adipose tissue, circulation and liver after lipectomy. The signaling pathways involved in the anti-steatotic effects of adiponectin have been evaluated in liver diseases in the absence of surgery. Whether these signaling pathways are similar in steatotic liver surgery remains to be elucidated. This is clinically important because drugs that regulate anabolic and catabolic effects (as in the case of adiponectin) require a certain pretreatment time before they exert their effects, and this is a major problem in LT from brain-dead or cardiac-arrest donors. The potential role of adiponectin in connecting the intestine and liver is scientifically and clinically interesting, and so is its role in regulating FGF15/19 signaling, which is of potential interest due to the benefits on bile acid homeostasis, a critical problem in liver diseases including NASH, cirrhosis and LT. However, appropriate experimental models are required to elucidate the relevance of adiponectin-FGF15/19 in liver diseases and surgery. This is also the case with the effects of adiponectin in fibrosis, since the results are mainly based on in vitro studies, far removed from clinical practice.

Different clinical results have been reported in relation with the levels of adiponectin and the pathological characteristics of NAFLD/NASH and its progression. In the context of hepatic resections and LT, the research into prognostic factors are of clinical and scientific relevance for the treatment of patients but the reported results are very limited and inconclusive. In our view, whether the levels of adiponectin reported in liver diseases might be the result of or the reason for the pathology, itself remains to be elucidated. Potential differences in the levels of adiponectin in liver diseases depending on gender should be considered (they have not been evaluated in detail to date). In addition, although adiponectin might be elevated in liver diseases, it might not exert protection if its receptor is downregulated or the adiponectin signaling pathway is dysfunctional. In addition, in line with other authors, in our view, adiponectin expression may initially be elevated to compensate disease progression, but then higher adiponectin levels could turn out to be ineffective because of an overall deterioration of the patient's condition [130]. All of these observations should be taken into account for future studies aimed at evaluating whether adiponectin can be considered a useful prognostic factor in different liver diseases in the presence or absence of surgery.

Author Contributions: Conceptualization, M.H., M.E.C.-P., M.B.J.-C. and C.P.; Writing-Original Draft Preparation, M.H., M.E.C-P., M.B.J.-C. and C.P.; Writing-Review and Editing, M.H., M.E.C-P., M.B.J-C. and C.P.; and Funding Acquisition, C.P. All authors have read and agree to the published version of the manuscript.

Funding: This research was supported by the Ministerio de Ciencia, Innovación y Universidades (RTI2018095114-B-I00) Madrid, Spain; European Union (Fondos Feder, "una manera de hacer Europa"); CERCA Program/Generalitat de Catalunya and Secretaria d'Universitats I Recerca del Departament d'Economia I Coneixement (2017 SGR-551) Barcelona, Spain.

Conflicts of Interest: The authors declare no conflict of interest. 
Abbreviations

\begin{tabular}{|c|c|}
\hline ACC & Acetyl-CoA carboxylase \\
\hline AdipoQ & Adiponectin, $\mathrm{C} 1 \mathrm{Q}$ and collagen domain containing \\
\hline AdipoR1/R2 & Adiponectin receptor type $1 / 2$ \\
\hline $\mathrm{And}^{-/-}$ & Adiponectin knockout \\
\hline AICAR & Aminoimidazole-4-carboxamide ribonucleoside \\
\hline Akt & Protein kinase B \\
\hline ALD & Alcoholic liver disease \\
\hline ALT & Alanine aminotransferase \\
\hline AMPK & Adenosine monophosphate-activated protein kinase \\
\hline Ang & Angiotensin \\
\hline APPL1 & Adaptor protein \\
\hline ATF6 & Activating transcription factor 6 \\
\hline ATP & Adenosine triphosphate \\
\hline CCL2 & C-C motif chemokine ligand 2 \\
\hline CHIP & C-terminus of Hsc70-interacting protein \\
\hline CPT-1 & Carnitine palmitoyl- transferase 1 \\
\hline CRP & C-reactive protein \\
\hline CXCL-10 & C-X-C motif chemokine ligand 10 \\
\hline Cyp7a1 & Cholesterol 7 alpha-hydroxylase \\
\hline $\mathrm{EC}$ & Endothelial cell \\
\hline eNOS & Endothelial nitric oxide synthase \\
\hline ER & Endoplasmic reticulum \\
\hline ET & Endothelin \\
\hline FA & Focal adhesion \\
\hline FAK & Focal adhesion kinase \\
\hline Fas & Fas-associated death domain \\
\hline $\mathrm{Fe}$ & Iron \\
\hline FGF2 & Fibroblast growth factor 2 \\
\hline FGF15/19 & Fibroblast growth factor 15/19 \\
\hline FOXO & Forkhead box protein $\mathrm{O}$ \\
\hline FXR & Farsenoid- $X$ receptor \\
\hline gAcrp30 & Globular adiponectin \\
\hline GSH & Glutathione \\
\hline $\mathrm{h}$ & Hours \\
\hline $\mathrm{HCC}$ & Hepatocellular carcinoma \\
\hline HFD & High fat diet \\
\hline HMW & High molecular weight \\
\hline $\mathrm{HO}-1$ & Heme oxygenase- 1 \\
\hline HOMA-IR & Homeostatic model assessment for insulin resistance \\
\hline HSC & Hepatic stellate cells \\
\hline $\mathrm{I} / \mathrm{R}$ & Ischemia/reperfusion \\
\hline ICAM & Intercellular cell adhesion molecule \\
\hline IFN & Interferon \\
\hline IL & Interleukin \\
\hline IRE1 & Inositol-requiring enzyme 1 \\
\hline Jak2 & Janus kinase 2 \\
\hline JNK & c-Jun N-terminal kinase \\
\hline KC & Kupffer cells \\
\hline $\mathrm{Ki}-67$ & Antigen Ki-67, a marker of proliferation \\
\hline $\mathrm{KO}$ & Knockout \\
\hline LCN2/SAA1 & Lipocalin-2/serum amyloid A1 \\
\hline LKB1 & Liver kinase B1 \\
\hline LMW & Low molecular weight \\
\hline LT & Liver transplantation \\
\hline
\end{tabular}




\begin{tabular}{|c|c|}
\hline MCD & Methionine-choline deficiency \\
\hline $\min$ & Minutes \\
\hline mLipin-1 & Myeloid cell-specific lipin-1 \\
\hline MMP-1 & Matrix metalloproteinase 1 \\
\hline MMW & Middle molecular weight \\
\hline $\mathrm{mNT}$ & MitoNEET \\
\hline $\mathrm{MPO}$ & Myeloperoxidase \\
\hline $\mathrm{m}-\mathrm{TOR}$ & Mammalian target of rapamycin \\
\hline MyD88 & Myeloid differentiation primary response gene 88 \\
\hline NAFLD & Nonalcoholic fatty liver disease \\
\hline $\mathrm{NASH}$ & Nonalcoholic steatohepatitis \\
\hline NF- $k B$ & $\begin{array}{l}\text { Nuclear factor kappa-light-chain-enhancer of } \\
\text { activated B cells }\end{array}$ \\
\hline $\mathrm{NO}$ & Nitric oxide \\
\hline $\mathrm{O}_{2}$ & Superoxide \\
\hline ONOO- & Peroxynitrite \\
\hline p38 & Mitogen-activated protein kinase p38 \\
\hline PDGF-BB & Platelet-derived growth factor-BB \\
\hline PERK & Protein kinase-like endoplasmic reticulum kinase \\
\hline PI3K & Phosphoinositide 3-kinase \\
\hline PPAR & Peroxisome proliferator-activated receptor \\
\hline PTP1B & Protein tyrosine phosphatase $1 \mathrm{~B}$ \\
\hline RBP4 & Retinol binding protein 4 \\
\hline ROS & Reactive oxygen species \\
\hline siRNA & Silent small interfering RNA \\
\hline SIRT1 & Sirtuin-1 \\
\hline$\alpha$-SMA & $\alpha$-smooth muscle actin \\
\hline SOCS3 & Suppressors of cytokine signaling 3 \\
\hline SOD & Superoxide dismutase \\
\hline SREBP-1c & Sterol regulatory element-binding protein $1 \mathrm{c}$ \\
\hline STAT3 & Signal transducer and activator of transcription 3 \\
\hline TGF- $\beta$ & Tumor growth factor beta \\
\hline TIMP-1 & Tissue inhibitor of metalloproteinase 1 \\
\hline TLR4 & Toll-like receptor 4 \\
\hline TNF- $\alpha$ & Tumor necrosis factor alpha \\
\hline TRAF6 & TNF receptor-associated factor 6 \\
\hline TRIF & $\begin{array}{l}\text { TIR-domain-containing adapter-inducing } \\
\text { interferon- } \beta\end{array}$ \\
\hline UPC2 & Uncoupling protein 2 \\
\hline UPR & Unfolded protein response \\
\hline $\mathrm{X} / \mathrm{XOD}$ & Xanthine/Xanthine oxidase \\
\hline $\mathrm{XOD}$ & Xanthine oxidase \\
\hline
\end{tabular}

\section{References}

1. Nocito, A.; El-Badry, A.M.; Clavien, P.A. When is steatosis too much for transplantation? J. Hepatol. 2006, 45, 494-499. [CrossRef] [PubMed]

2. Álvarez-Mercado, A.I.; Gulfo, J.; Romero-Gómez, M.; Jiménez-Castro, M.B.; Gracia-Sancho, J.; Peralta, C. Use of steatotic grafts in liver transplantation: Current status. Liver Transpl. 2019, 25, 771-786. [CrossRef] [PubMed]

3. Peralta, C.; Jiménez-Castro, M.B.; Gracia-Sancho, J. Hepatic ischemia and reperfusion injury: Effects on the liver sinusoidal milieu. J. Hepatol. 2013, 59, 1094-1106. [CrossRef] [PubMed]

4. Tsutamoto, T.; Tanaka, T.; Sakai, H.; Ishikawa, C.; Fujii, M.; Yamamoto, T.; Horie, M. Total and high molecular weight adiponectin, haemodynamics, and mortality in patients with chronic heart failure. Eur. Heart J. 2007, 28, 1723-1730. [CrossRef] [PubMed] 
5. Zhu, W.; Cheng, K.K.; Vanhoutte, P.M.; Lam, K.S.; Xu, A. Vascular effects of adiponectin: Molecular mechanisms and potential therapeutic intervention. Clin. Sci. 2008, 114, 361-374. [CrossRef] [PubMed]

6. Bianchi, G.; Bugianesi, E.; Frystyk, J.; Tarnow, L.; Flyvbjerg, A.; Marchesini, G. Adiponectin isoforms, insulin resistance and liver histology in nonalcoholic fatty liver disease. Dig. Liver Dis. 2011, 43, 73-77. [CrossRef]

7. Adachi, M.; Brenner, D.A. High molecular weight adiponectin inhibits proliferation of hepatic stellate cells via activation of adenosine monophosphate-activated protein kinase. Hepatology 2008, 47, 677-685. [CrossRef]

8. Wang, Y.; Lu, G.; Wong, W.P.; Vliegenthart, J.F.; Gerwig, G.J.; Lam, K.S.; Cooper, G.J.; Xu, A. Proteomic and functional characterization of endogenous adiponectin purified from fetal bovine serum. Proteomics 2004, 4, 3933-3942. [CrossRef]

9. Massip-Salcedo, M.; Zaouali, M.A.; Padrissa-Altés, S.; Casillas-Ramirez, A.; Rodés, J.; Roselló-Catafau, J.; Peralta, C. Activation of peroxisome proliferator-activated receptor-alpha inhibits the injurious effects of adiponectin in rat steatotic liver undergoing ischemia-reperfusion. Hepatology 2008, 47, 461-472. [CrossRef]

10. Arita, Y.; Kihara, S.; Ouchi, N.; Takahashi, M.; Maeda, K.; Miyagawa, J.; Hotta, K.; Shimomura, I.; Nakamura, T.; Miyaoka, K.; et al. Paradoxical decrease of an adipose-specific protein, adiponectin, in obesity. Biochem. Biophys. Res. Commun. 1999, 257, 79-83. [CrossRef]

11. Hu, E.; Liang, P.; Spiegelman, B.M. AdipoQ is a novel adipose-specific gene dysregulated in obesity. J. Biol. Chem. 1996, 271, 10697-10703. [CrossRef] [PubMed]

12. Stefan, N.; Bunt, J.C.; Salbe, A.D.; Funahashi, T.; Matsuzawa, Y.; Tataranni, P.A. Plasma adiponectin concentrations in children: Relationships with obesity and insulinemia. J. Clin. Endocrinol. Metab. 2002, 87, 4652-4656. [CrossRef]

13. Ostrowska, L.; Fiedorczuk, J.; Adamska, E. Effect of diet and other factors on serum adiponectin concentrations in 49 patients with type 2 diabetes. Roczniki Państwowego Zakładu Higieny 2013, 64, 61-66. [PubMed]

14. Yatagai, T.; Nagasaka, S.; Taniguchi, A.; Fukushima, M.; Nakamura, T.; Kuroe, A.; Nakai, Y.; Ishibashi, S. Hypoadiponectinemia is associated with visceral fat accumulation and insulin resistance in Japanese men with type 2 diabetes mellitus. Metabolism 2003, 52, 1274-1278. [CrossRef]

15. Bidulescu, A.; Liu, J.; Hickson, D.A.; Hairston, K.G.; Fox, E.R.; Arnett, D.K.; Sumner, A.E.; Taylor, H.A.; Gibbons, G.H. Gender differences in the association of visceral and subcutaneous adiposity with adiponectin in African americans: The jackson heart study. BMC Cardiovasc. Disord. 2013, 13, 9-19. [CrossRef]

16. Jiménez-Castro, M.B.; Casillas-Ramírez, A.; Mendes-Braz, M.; Massip-Salcedo, M.; Gracia-Sancho, J.; Elias-Miró, M.; Rodés, J.; Peralta, C. Adiponectin and resistin protect steatotic livers undergoing transplantation. J. Hepatol. 2013, 59, 1208-1214. [CrossRef]

17. Tsai, C.Y.; Lin, Y.S.; Yeh, T.S.; Cheong, C.F.; Chang, C.H.; Chen, T.C.; Chen, M.F. Disrupted hepatic adiponectin signaling impairs liver regeneration of steatotic rats. Chang Gung Med. J. 2011, 34, 248-259.

18. Deepa, S.S.; Dong, L.Q. APPL1: Role in adiponectin signaling and beyond. Am. J. Physiol. Endocrinol. Metab. 2009, 296, E22-E36. [CrossRef]

19. Holmes, R.M.; Yi, Z.; De Filippis, E.; Berria, R.; Shahani, S.; Sathyanarayana, P.; Sherman, V.; Fujiwara, K.; Meyer, C.; Christ-Roberts, C.; et al. Increased abundance of the adaptor protein containing pleckstrin homology domain, phosphotyrosine binding domain and leucine zipper motif (APPL1) in patients with obesity and type 2 diabetes: Evidence for altered adiponectin signalling. Diabetologia 2011, 54, 2122-2131. [CrossRef]

20. Tarantino, G.; Savastano, S.; Colao, A. Hepatic steatosis, low-grade chronic inflammation and hormone/growth factor/adipokine imbalance. World J. Gastroenterol. 2010, 16, 4773-4783. [CrossRef]

21. Ma, H.; Gomez, V.; Lu, L.; Yang, X.; Wu, X.; Xiao, S.Y. Expression of adiponectin and its receptors in livers of morbidly obese patients with non-alcoholic fatty liver disease. J. Gastroenterol. Hepatol. 2009, 24, $233-237$. [CrossRef] [PubMed]

22. Nannipieri, M.; Cecchetti, F.; Anselmino, M.; Mancini, E.; Marchetti, G.; Bonotti, A.; Baldi, S.; Solito, B.; Giannetti, M.; Pinchera, A.; et al. Pattern of expression of adiponectin receptors in human liver and its relation to nonalcoholic steatohepatitis. Obes. Surg. 2009, 19, 467-474. [CrossRef] [PubMed]

23. Tiniakos, D.G. Nonalcoholic fatty liver disease/nonalcoholic steatohepatitis: Histological diagnostic criteria and scoring systems. Eur. J. Gastroenterol. Hepatol. 2010, 22, 643-650. [CrossRef] [PubMed]

24. Vuppalanchi, R.; Marri, S.; Kolwankar, D.; Considine, R.V.; Chalasani, N. Is adiponectin involved in the pathogenesis of nonalcoholic steatohepatitis? A preliminary human study. J. Clin. Gastroenterol. 2005, 39, 237-242. [CrossRef] [PubMed] 
25. Fujikawa, T.; Hirata, T.; Wada, A.; Kawamura, N.; Yamaguchi, Y.; Fujimura, K.; Ueda, T.; Yurugi, Y.; Soya, H.; Nishibe, S. Chronic administration of Eucommia leaf stimulates metabolic function of rats across several organs. Br. J. Nutr. 2010, 104, 1868-1877. [CrossRef] [PubMed]

26. Baranova, A.; Gowder, S.J.; Schlauch, K.; Elariny, H.; Collantes, R.; Afendy, A.; Ong, J.P.; Goodman, Z.; Chandhoke, V.; Younossi, Z.M. Gene expression of leptin, resistin, and adiponectin in the white adipose tissue of obese patients with non-alcoholic fatty liver disease and insulin resistance. Obes. Surg. 2006, 16, 1118-1125. [CrossRef]

27. Jiang, L.L.; Li, L.; Hong, X.F.; Li, Y.M.; Zhang, B.L. Patients with nonalcoholic fatty liver disease display increased serum resistin levels and decreased adiponectin levels. Eur. J. Gastroenterol. Hepatol. 2009, 21, 662-666. [CrossRef]

28. Jiménez-Castro, M.B.; Meroño, N.; Mendes-Braz, M.; Gracia-Sancho, J.; Martínez-Carreres, L.; Cornide-Petronio, M.E.; Casillas-Ramirez, A.; Rodés, J.; Peralta, C. The effect of brain death in rat steatotic and non-steatotic liver transplantation with previous ischemic preconditioning. J. Hepatol. 2015, 62, 83-91. [CrossRef]

29. Ezaki, H.; Yoshida, Y.; Saji, Y.; Takemura, T.; Fukushima, J.; Matsumoto, H.; Kamada, Y.; Wada, A.; Igura, T.; Kihara, S.; et al. Delayed liver regeneration after partial hepatectomy in adiponectin knockout mice. Biochem. Biophys. Res. Commun. 2009, 378, 68-72. [CrossRef]

30. Shu, R.Z.; Zhang, F.; Wang, F.; Feng, D.C.; Li, X.H.; Ren, W.H.; Wu, X.L.; Yang, X.; Liao, X.D.; Huang, L.; et al. Adiponectin deficiency impairs liver regeneration through attenuating STAT3 phosphorylation in mice. Lab. Invest. 2009, 89, 1043-1052. [CrossRef]

31. Correnti, J.M.; Cook, D.; Aksamitiene, E.; Swarup, A.; Ogunnaike, B.; Vadigepalli, R.; Hoeck, J.B. Adiponectin fine-tuning of liver regeneration dynamics revealed through cellular network modelling. J. Physiol. 2015, 593, 365-383. [CrossRef] [PubMed]

32. Sturm, J.; Keese, M.; Zhang, H.; Bönninghoff, R.; Magdeburg, R.; Vajkoczy, P.; Dono, R.; Zeller, R.; Gretz, N. Liver regeneration in FGF-2-deficient mice: VEGF acts as potential functional substitute for FGF-2. Liver Int. 2004, 24, 161-168. [CrossRef] [PubMed]

33. Berg, A.H.; Combs, T.P.; Du, X.; Brownlee, M.; Scherer, P.E. The adipocyte-secreted protein Acrp30 enhances hepatic insulin action. Nat. Med. 2001, 7, 947-953. [CrossRef] [PubMed]

34. Kamada, Y.; Takehara, T.; Hayashi, N. Adipocytokines and liver disease. J. Gastroenterol. 2008, 43, 811-822. [CrossRef] [PubMed]

35. Awazawa, M.; Ueki, K.; Inabe, K.; Yamauchi, T.; Kaneko, K.; Okazaki, Y.; Bardeesy, N.; Ohnishi, S.; Nagai, R.; Kadowaki, T. Adiponectin suppresses hepatic SREBP1c expression in an AdipoR1/LKB1/AMPK dependent pathway. Biochem. Biophys. Res. Commun. 2009, 382, 51-56. [CrossRef] [PubMed]

36. Shklyaev, S.; Aslanidi, G.; Tennant, M.; Prima, V.; Kohlbrenner, E.; Kroutov, V.; Campbell-Thompson, M.; Crawford, J.; Shek, E.W.; Scarpace, P.J.; et al. Sustained peripheral expression of transgene adiponectin offsets the development of diet-induced obesity in rats. Proc. Nat. Acad. Sci. USA 2003, 100, 14217-14222. [CrossRef]

37. Hardie, D.G.; Pan, D.A. Regulation of fatty acid synthesis and oxidation by the AMP-activated protein kinase. Biochem. Soc. Trans. 2002, 30, 1064-1070. [CrossRef]

38. You, M.; Rogers, C.Q. Adiponectin: A key adipokine in alcoholic fatty liver. Exp. Biol. Med. 2009, 234, 850-859. [CrossRef]

39. Ohashi, K.; Shibata, R.; Murohara, T.; Ouchi, N. Role of anti-inflammatory adipokines in obesity-related diseases. Trends Endocrinol. Metab. 2014, 25, 348-355. [CrossRef]

40. Watt, K.D.; Fan, C.; Therneau, T.; Heimbach, J.K.; Seaberg, E.C.; Charlton, M.R. Serum adipokine and inflammatory markers before and after liver transplantation in recipients with major cardiovascular events. Liver Transpl. 2014, 20, 791-797. [CrossRef]

41. Fernández, L.; Heredia, N.; Grande, L.; Gómez, G.; Rimola, A.; Marco, A.; Gelpí, E.; Roselló-Catafau, J.; Peralta, C. Preconditioning protects liver and lung damage in rat liver transplantation: Role of xanthine/xanthine oxidase. Hepatology 2002, 36, 562-572. [CrossRef] [PubMed]

42. Peralta, C.; Perales, J.C.; Bartrons, R.; Mitchell, C.; Gilgenkrantz, H.; Xaus, C.; Prats, N.; Fernández, L.; Gelpí, E.; Panés, J.; et al. The combination of ischemic preconditioning and liver Bcl-2 overexpression is a suitable strategy to prevent liver and lung damage after hepatic ischemia-reperfusion. Am. J. Pathol. 2002, 160, 2111-2122. [CrossRef] 
43. Saxena, N.K.; Anania, F.A. Adipocytokines and hepatic fibrosis. Trends Endocrinol. Metab. 2015, 26, $153-161$. [CrossRef] [PubMed]

44. Buechler, C.; Haberl, E.M.; Rein-Fischboeck, L.; Aslanidis, C. Adipokines in liver cirrhosis. Int. J. Mol. Sci. 2017, 18, 1392. [CrossRef]

45. Kaser, S.; Moschen, A.; Kaser, A.; Ludwiczek, O.; Ebenbichler, C.F.; Vogel, W.; Jaschke, W.; Patsch, J.R.; Tilg, H. Circulating adiponectin reflects severity of liver disease but not insulin sensitivity in liver cirrhosis. J. Intern. Med. 2005, 258, 274-280. [CrossRef]

46. Tacke, F.; Wüstefeld, T.; Horn, R.; Luedde, T.; Rao, A.S.; Manns, M.P.; Trautwein, C.; Brabant, G. High adiponectin in chronic liver disease and cholestasis suggests biliary route of adiponectin excretion in vivo. $J$. Hepatol. 2005, 42, 666-673. [CrossRef]

47. Sohara, N.; Takagi, H.; Kakizaki, S.; Sato, K.; Mori, M. Elevated plasma adiponectin concentrations in patients with liver cirrhosis correlate with plasma insulin levels. Liver Int. 2005, 25, 28-32. [CrossRef]

48. Adolph, T.E.; Grander, C.; Grabherr, F.; Tilg, H. Adipokines and non-alcoholic fatty liver disease: Multiple interactions. Int. J. Mol. Sci. 2017, 18, 1649. [CrossRef]

49. Kamada, Y.; Matsumoto, H.; Tamura, S.; Fukushima, J.; Kiso, S.; Fukui, K.; Igura, T.; Maeda, N.; Kihara, S.; Funahashi, T.; et al. Hypoadiponectinemia accelerates hepatic tumor formation in a nonalcoholic steatohepatitis mouse model. J. Hepatol. 2007, 47, 556-564. [CrossRef]

50. Saxena, N.K.; Fu, P.P.; Nagalingam, A.; Wang, J.; Handy, J.; Cohen, C.; Tighiouart, M.; Sharma, D.; Anania, F.A. Adiponectin modulates C-jun N-terminal kinase and mammalian target of rapamycin and inhibits hepatocellular carcinoma. Gastroenterology 2010, 139, 1762-1773.e1-5. [CrossRef]

51. Hui, J.M.; Hodge, A.; Farrell, G.C.; Kench, J.G.; Kriketos, A.; George, J. Beyond insulin resistance in NASH: TNF-alpha or adiponectin? Hepatology 2004, 40, 46-54. [CrossRef] [PubMed]

52. Moschen, A.R.; Molnar, C.; Wolf, A.M.; Weiss, H.; Graziadei, I.; Kaser, S.; Ebenbichler, C.F.; Stadlmann, S.; Moser, P.L.; Tilg, H. Effects of weight loss induced by bariatric surgery on hepatic adipocytokine expression. J. Hepatol. 2009, 51, 765-777. [CrossRef] [PubMed]

53. Al-Gayyar, M.M.; Abbas, A.; Hamdan, A.M. Chemopreventive and hepatoprotective roles of adiponectin (SULF2 inhibitor) in hepatocelluar carcinoma. Biol. Chem. 2016, 397, 257-267. [CrossRef]

54. Deng, T.; Lyon, C.J.; Bergin, S.; Caligiuri, M.A.; Hsueh, W.A. Obesity, inflammation, and cancer. Annu. Rev. Pathol. 2016, 11, 421-449. [CrossRef]

55. Wang, S.N.; Yeh, Y.T.; Yang, S.F.; Chai, C.Y.; Lee, K.T. Potential role of leptin expression in hepatocellular carcinoma. J. Clin. Pathol. 2006, 59, 930-934. [CrossRef] [PubMed]

56. Shin, E.; Yu, Y.D.; Kim, D.S.; Won, N.H. Adiponectin receptor expression predicts favorable prognosis in cases of hepatocellular carcinoma. Pathol. Oncol. Res. 2014, 20, 667-675. [CrossRef]

57. Wang, S.N.; Yang, S.F.; Tsai, H.H.; Lee, K.T.; Yeh, Y.T. Increased adiponectin associated with poor survival in hepatocellular carcinoma. J. Gastroenterol. 2014, 49, 1342-1351. [CrossRef]

58. Kasztelan-Szczerbinska, B.; Surdacka, A.; Slomka, M.; Rolinski, J.; Celinski, K.; Smolen, A.; Szczerbinski, M. Association of serum adiponectin, leptin, and resistin concentrations with the severity of liver dysfunction and the disease complications in alcoholic liver disease. Mediat. Inflamm. 2013, 2013, 148526. [CrossRef]

59. Manieri, E.; Herrera-Melle, L.; Mora, A.; Tomás-Loba, A.; Leiva-Vega, L.; Fernández, D.I.; Rodríguez, E.; Morán, L.; Hernández-Cosido, L.; Torres, J.L.; et al. Adiponectin accounts for gender differences in hepatocellular carcinoma incidence. J. Exp. Med. 2019, 216, 1108-1119. [CrossRef]

60. Zhang, C.; Liao, Y.; Li, Q.; Chen, M.; Zhao, Q.; Deng, R.; Wu, C.; Yang, A.; Guo, Z.; Wang, D.; et al. Recombinant adiponectin ameliorates liver ischemia reperfusion injury via activating the AMPK/eNOS pathway. PLoS ONE 2013, 8, e66382. [CrossRef]

61. Ding, W.; Zhang, Q.; Dong, Y.; Ding, N.; Huang, H.; Zhu, X.; Hutchinson, S.; Gao, X.; Zhang, X. Adiponectin protects the rats liver against chronic intermittent hypoxia induced injury through AMP-activated protein kinase pathway. Sci. Rep. 2016, 6, 34151. [CrossRef]

62. Xia, Y.; Gong, J.P. Impact of recombinant globular adiponectin on early warm ischemia-reperfusion injury in rat bile duct after liver transplantation. Sci. Rep. 2014, 4, 1-9. [CrossRef] [PubMed]

63. Turmelle, Y.P.; Shikapwashya, O.; Tu, S.; Hruz, P.W.; Yan, Q.; Rudnick, D.A. Rosiglitazone inhibits mouse liver regeneration. FASEB J. 2006, 20, 2609-2611. [CrossRef] [PubMed] 
64. Mendes-Braz, M.; Elias-Miró, M.; Kleuser, B.; Fayyaz, S.; Jiménez-Castro, M.B.; Massip-Salcedo, M.; Gracia-Sancho, J.; Ramalho, F.S.; Rodes, J.; Peralta, C. The effects of glucose and lipids in steatotic and non-steatotic livers in conditions of partial hepatectomy under ischaemia-reperfusion. Liver Int. 2014, 34, e271-e289. [CrossRef] [PubMed]

65. Parkin, E.; O’Reilly, D.A.; Plumb, A.A.; Manoharan, P.; Rao, M.; Coe, P.; Frystyk, J.; Ammori, B.; de Liguori Carino, N.; Deshpande, R.; et al. Digital histology quantification of intra-hepatic fat in patients undergoing liver resection. Eur. J. Surg. Oncol. 2015, 41, 1020-1027. [CrossRef] [PubMed]

66. Mandal, P.; Roychowdhury, S.; Park, P.H.; Pratt, B.T.; Roger, T.; Nagy, L.E. Adiponectin and heme oxygenase-1 suppress TLR4/MyD88-independent signaling in rat Kupffer cells and in mice after chronic ethanol exposure. J. Immunol. 2010, 185, 4928-4937. [CrossRef] [PubMed]

67. Yamauchi, T.; Nio, Y.; Maki, T.; Kobayashi, M.; Takazawa, T.; Iwabu, M.; Okada-Iwabu, M.; Kawamoto, S.; Kubota, N.; Kubota, T.; et al. Targeted disruption of AdipoR1 and AdipoR2 causes abrogation of adiponectin binding and metabolic actions. Nat. Med. 2007, 13, 332-339. [CrossRef] [PubMed]

68. Kim, S.M.; Grenert, J.P.; Patterson, C.; Correia, M.A. CHIP (-/-)-mouse liver: Adiponectin-AMPKFOXO-activation overrides CYP2E1-elicited JNK1-activation, delaying onset of NASH: Therapeutic implications. Sci. Rep. 2016, 6, 29423. [CrossRef]

69. Wang, J.; Kim, C.; Jogasuria, A.; Han, Y.; Hu, X.; Wu, J.; Shen, H.; Chrast, R.; Finck, B.N.; You, M. Myeloid cell-specific lipin-1 deficiency stimulates endocrine adiponectin-FGF15 axis and ameliorates ethanol-induced liver injury in mice. Sci. Rep. 2016, 6, 34117. [CrossRef]

70. Hu, X.; Jogasuria, A.; Wang, J.; Kim, C.; Han, Y.; Shen, H.; Wu, J.; You, M. MitoNEET deficiency alleviates experimental alcoholic steatohepatitis in mice by stimulating endocrine adiponectin-Fgf15 Axis. J. Biol. Chem. 2016, 291, 22482-22495. [CrossRef]

71. Bechmann, L.P.; Kocabayoglu, P.; Sowa, J.P.; Sydor, S.; Best, J.; Schlattjan, M.; Beilfuss, A.; Schmitt, J.; Hannivoort, R.A.; Kilicarslan, A.; et al. Free fatty acids repress small heterodimer partner (SHP) activation and adiponectin counteracts bile acid-induced liver injury in super obese patients with nonalcoholic steatohepatitis. Hepatology 2013, 57, 1394-1406. [CrossRef]

72. You, M.; Zhou, Z.; Daniels, M.; Jogasuria, A. Endocrine adiponectin-FGF15/19 axis in ethanol-induced inflammation and alcoholic liver injury. Gene Expr. 2018, 18, 103-113. [CrossRef] [PubMed]

73. Gulfo, J.; Rotondo, F.; Ávalos de León, C.G.; Cornide-Petronio, M.E.; Fuster, C.; Gracia-Sancho, J.; Jiménez-Castro, M.B.; Peralta, C. FGF15 improves outcomes after brain dead donor liver transplantation with steatotic and non-steatotic grafts in rats. J. Hepatol. 2020, 30299-30303. [CrossRef]

74. Finelli, C.; Tarantino, G. What is the role of adiponectin in obesity related non-alcoholic fatty liver disease? World J. Gastroenterol. 2013, 19, 802-812. [CrossRef]

75. Gastaldelli, A.; Harrison, S.; Belfort-Aguiar, R.; Hardies, J.; Balas, B.; Schenker, S.; Cusi, K. Pioglitazone in the treatment of NASH: The role of adiponectin. Aliment. Pharmacol. Ther. 2010, 32, 769-775. [CrossRef] [PubMed]

76. Lutchman, G.; Promrat, K.; Kleiner, D.E.; Heller, T.; Ghany, M.G.; Yanovski, J.A.; Liang, T.J.; Hoofnagle, J.H. Changes in serum adipokine levels during pioglitazone treatment for nonalcoholic steatohepatitis: Relationship to histological improvement. Clin. Gastroenterol. Hepatol. 2006, 4, 1048-1052. [CrossRef]

77. Landrier, J.F.; Gouranton, E.; El Yazidi, C.; Malezet, C.; Balaguer, P.; Borel, P.; Amiot, M.J. Adiponectin expression is induced by vitamin $\mathrm{E}$ via a peroxisome proliferator-activated receptor gamma-dependent mechanism. Endocrinology 2009, 150, 5318-5325. [CrossRef]

78. Shen, Z.; Liang, X.; Rogers, C.Q.; Rideout, D.; You, M. Involvement of adiponectin-SIRT1-AMPK signaling in the protective action of rosiglitazone against alcoholic fatty liver in mice. Am. J. Physiol. Gastrointest. Liver Physiol. 2010, 298, G364-G374. [CrossRef]

79. Hume, M.P.; Nicolucci, A.C.; Reimer, R.A. Prebiotic supplementation improves appetite control in children with overweight and obesity: A randomized controlled trial. Am. J. Clin. Nutr. 2017, 105, 790-799. [CrossRef]

80. Kadooka, Y.; Sato, M.; Imaizumi, K.; Ogawa, A.; Ikuyama, K.; Akai, Y.; Okano, M.; Kagoshima, M.; Tsuchida, T. Regulation of abdominal adiposity by probiotics (Lactobacillus gasseri SBT2055) in adults with obese tendencies in a randomized controlled trial. Eur. J. Clin. Nutr. 2010, 64, 636-643. [CrossRef]

81. Shetty, S.; Kusminski, C.M.; Scherer, P.E. Adiponectin in health and disease: Evaluation of adiponectin-targeted drug development strategies. Trends Pharmacol. Sci. 2009, 30, 234-239. [CrossRef] [PubMed] 
82. Gonciarz, M.; Bielański, W.; Partyka, R.; Brzozowski, T.; Konturek, P.C.; Eszyk, J.; Celiński, K.; Reiter, R.J.; Konturek, S.J. Plasma insulin, leptin, adiponectin, resistin, ghrelin, and melatonin in nonalcoholic steatohepatitis patients treated with melatonin. J. Pineal Res. 2013, 54, 154-161. [CrossRef] [PubMed]

83. Polyzos, S.A.; Kountouras, J.; Zavos, C.; Tsiaousi, E. The role of adiponectin in the pathogenesis and treatment of non-alcoholic fatty liver disease. Diabetes Obes. Metab. 2010, 12, 365-383. [CrossRef] [PubMed]

84. Ali Khan, R.; Kapur, P.; Jain, A.; Farah, F.; Bhandari, U. Effect of orlistat on periostin, adiponectin, inflammatory markers and ultrasound grades of fatty liver in obese NAFLD patients. Ther. Clin. Risk Manag. 2017, 13, 139-149. [CrossRef]

85. Galeno, A.; Tan, D.X.; Reiter, R.J. Melatonin as a natural ally against oxidative stress: A physicochemical examination. J. Pineal Res. 2011, 51, 1-16. [CrossRef]

86. Konturek, S.J.; Konturek, P.C.; Brzozowski, T.; Bubenik, G.A. Role of melatonin in upper gastrointenstinal tract. J. Physiol. Pharmacol. 2007, 58, 23-52.

87. Polyzos, S.A.; Kountouras, J.; Zavos, C. Adiponectin as a potential therapeutic agent for nonalcoholic steatohepatitis. Hepatol. Res. 2010, 40, 446-447. [CrossRef]

88. Polyzos, S.A.; Kountouras, J.; Zavos, C. Adiponectin in non-alcoholic fatty liver disease treatment: Therapeutic perspectives and unresolved dilemmas. Int J. Clin. Pract. 2011, 65, 373-374. [CrossRef]

89. Narasimhan, M.L.; Coca, M.A.; Jin, J.; Yamauchi, T.; Ito, Y.; Kadowaki, T.; Kim, K.K.; Pardo, J.M.; Damsz, B.; Hasegawa, P.M.; et al. Osmotin is a homolog of mammalian adiponectin and controls apoptosis in yeast through a homolog of mammalian adiponectin receptor. Mol. Cell 2005, 17, 171-180. [CrossRef]

90. Razavizade, M.; Jamali, R.; Arj, A.; Matini, S.M.; Moraveji, A.; Taherkhani, E. The effect of pioglitazone and metformin on liver function tests, insulin resistance, and liver fat content in nonalcoholic Fatty liver disease: A randomized double blinded clinical trial. Hepat. Mon. 2013, 13, e9270. [CrossRef]

91. Promrat, K.; Lutchman, G.; Uwaifo, G.I.; Freedman, R.J.; Soza, A.; Heller, T.; Doo, E.; Ghany, M.; Premkumar, A.; Park, Y.; et al. A pilot study of pioglitazone treatment for nonalcoholic steatohepatitis. Hepatology 2004, 39, 188-196. [CrossRef] [PubMed]

92. Sanyal, A.J.; Mofrad, P.S.; Contos, M.J.; Sargeant, C.; Luketic, V.A.; Sterling, R.K.; Stravitz, R.T.; Shiffman, M.L.; Clore, J.; Mills, A.S. A pilot study of vitamin E versus vitamin E and pioglitazone for the treatment of nonalcoholic steatohepatitis. Clin. Gastroenterol. Hepatol. 2004, 2, 1107-1115. [CrossRef]

93. Lutchman, G.; Modi, A.; Kleiner, D.E.; Promrat, K.; Heller, T.; Ghany, M.; Borg, B.; Loomba, R.; Liang, T.J.; Premkumar, A.; et al. The effects of discontinuing pioglitazone in patients with nonalcoholic steatohepatitis. Hepatology 2007, 46, 424-429. [CrossRef] [PubMed]

94. Belfort, R.; Harrison, S.A.; Brown, K.; Darland, C.; Finch, J.; Hardies, J.; Balas, B.; Gastaldelli, A.; Tio, F.; Pulcini, J.; et al. A placebo-controlled trial of pioglitazone in subjects with nonalcoholic steatohepatitis. $N$. Engl. J. Med. 2006, 355, 2297-2307. [CrossRef] [PubMed]

95. Liss, K.H.; Finck, B.N. PPARs and nonalcoholic fatty liver disease. Biochimie 2017, 136, 65-74. [CrossRef] [PubMed]

96. Matsusue, K.; Haluzik, M.; Lambert, G.; Yim, S.H.; Gavrilova, O.; Ward, J.M.; Brewer, B.; Reitman, M.L.; Gonzalez, F.J. Liver-specific disruption of PPAR $\gamma$ in leptin-deficient mice improves fatty liver but aggravates diabetic phenotypes. J. Clin. Invest. 2003, 111, 737-747. [CrossRef] [PubMed]

97. García-Ruiz, I.; Rodríguez-Juan, C.; Díaz-Sanjuán, T.; Martínez, M.Á.; Muñoz-Yagüe, T.; Solís-Herruzo, J.A. Effects of rosiglitazone on the liver histology and mitochondrial function in ob/ob mice. Hepatology 2007, 46, 414-423. [CrossRef]

98. Hadi, H.E.; Vettor, R.; Rossato, M. Vitamin E as a treatment for nonalcoholic fatty liver disease: Reality or myth? Antioxidants 2018, 7, 12. [CrossRef]

99. Schürks, M.; Glynn, R.J.; Rist, P.M.; Tzourio, C.; Kurth, T. Effects of vitamin E on stroke subtypes: Meta-analysis of randomised controlled trials. BMJ 2010, 341, c5702. [CrossRef]

100. Klein, E.A.; Thompson, I.M.; Tangen, C.M.; Crowley, J.J.; Lucia, M.S.; Goodman, P.J.; Minasian, L.M.; Ford, L.G.; Parnes, H.L.; Gaziano, J.M.; et al. Vitamin E and the risk of prostate cancer: The Selenium and Vitamin E Cancer Prevention Trial (SELECT). JAMA 2011, 306, 1549-1556. [CrossRef]

101. Hemmeryckx, B.; Gaekens, M.; Gallacher, D.J.; Lu, H.R.; Lijnen, H.R. Effect of rosiglitazone on liver structure and function in genetically diabetic Akita mice. Basic Clin. Pharmacol. Toxicol. 2013, 113, 353-360. [CrossRef] [PubMed] 
102. Abbas, A.; Blandon, J.; Rude, J.; Elfar, A.; Mukherjee, D. PPAR- $\gamma$ agonist in treatment of diabetes: Cardiovascular safety considerations. Cardiovasc. Hematol. Agents Med. Chem. 2012, 10, 124-134. [CrossRef] [PubMed]

103. Douglas, I.J.; Langham, J.; Bhaskaran, K.; Brauer, R.; Smeeth, L. Orlistat and the risk of acute liver injury: Self controlled case series study in UK clinical practice research datalink. BMJ 2013, 346, f1936. [CrossRef] [PubMed]

104. Eroglu, E.; Gemici, G.; Bayrak, F.; Kalkan, A.K.; Degertekin, M. Acute myocardial infarction in a 24 year-old man possibly associated with sibutramine use. Int. J. Cardiol. 2009, 137, e43-e45. [CrossRef] [PubMed]

105. Chavez-Tapia, N.C.; Tellez-Avila, F.I.; Bedogni, G.; Crocè, L.S.; Masutti, F.; Tiribelli, C. Systematic review and meta-analysis on the adverse events of rimonabant treatment: Considerations for its potential use in hepatology. BMC Gastroenterol. 2009, 9, 75. [CrossRef]

106. Halberg, N.; Schraw, T.D.; Wang, Z.V.; Kim, J.Y.; Yi, J.; Hamilton, M.P.; Luby-Phelps, K.; Scherer, P.E. Systemic fate of the adipocyte-derived factor adiponectin. Diabetes 2009, 58, 1961-1970. [CrossRef]

107. Kadowaki, T.; Yamauchi, T.; Kubota, N.; Hara, K.; Ueki, K. Adiponectin and adiponectin receptors in obesity-linked insulin resistance. Novartis Found. Symp. 2007, 286, 164-176. [CrossRef]

108. Neumeier, M.; Hellerbrand, C.; Gäbele, E.; Buettner, R.; Bollheimer, C.; Weigert, J.; Schäffler, A.; Weiss, T.S.; Lichtenauer, M.; Schölmerich, J.; et al. Adiponectin and its receptors in rodent models of fatty liver disease and liver cirrhosis. World J. Gastroenterol. 2006, 12, 5490-5494. [CrossRef]

109. Musso, G.; Gambino, R.; Cassader, M. Recent insights into hepatic lipid metabolism in non-alcoholic fatty liver disease (NAFLD). Prog. Lipid Res. 2009, 48, 1-26. [CrossRef]

110. Gatselis, N.K.; Ntaios, G.; Makaritsis, K.; Dalekos, G.N. Adiponectin: A key playmaker adipocytokine in non-alcoholic fatty liver disease. Clin. Exp. Med. 2014, 14, 121-131. [CrossRef]

111. Polyzos, S.A.; Toulis, K.A.; Goulis, D.G.; Zavos, C.; Kountouras, J. Serum total adiponectin in non-alcoholic fatty liver disease: A systematic review and meta-analysis. Metabolism 2011, 60, 313-326. [CrossRef]

112. Lian, K.; Feng, Y.N.; Li, R.; Liu, H.L.; Han, P.; Zhou, L.; Li, C.X.; Wang, Q. Middle- and high-molecular weight adiponectin levels in relation to nonalcoholic fatty liver disease. J. Clin. Lab. Anal. 2020, 34, e23148. [CrossRef] [PubMed]

113. Ozcelik, F.; Yuksel, C.; Arslan, E.; Genc, S.; Omer, B.; Serdar, M.A. Relationship between visceral adipose tissue and adiponectin, inflammatory markers and thyroid hormones in obese males with hepatosteatosis and insulin resistance. Arch. Med. Res. 2013, 44, 273-280. [CrossRef] [PubMed]

114. Balmer, M.L.; Joneli, J.; Schoepfer, A.; Stickel, F.; Thormann, W.; Dufour, J.F. Significance of serum adiponectin levels in patients with chronic liver disease. Clin. Sci. 2010, 119, 431-436. [CrossRef] [PubMed]

115. Jamali, R.; Arj, A.; Razavizade, M.; Aarabi, M.H. Prediction of nonalcoholic fatty liver disease via a novel panel of serum adipokines. Medicine 2016, 95, e2630. [CrossRef]

116. Targher, G.; Bertolini, L.; Scala, L.; Poli, F.; Zenari, L.; Falezza, G. Decreased plasma adiponectin concentrations are closely associated with nonalcoholic hepatic steatosis in obese individuals. Clin. Endocrinol. 2004, 61, 700-703. [CrossRef]

117. Wong, V.W.; Wong, G.L.; Choi, P.C.; Chan, A.W.; Li, M.K.; Chan, H.Y.; Chim, A.M.; Yu, J.; Sung, J.J.; Chan, H.L. Disease progression of non-alcoholic fatty liver disease: A prospective study with paired liver biopsies at 3 years. Gut 2010, 59, 969-974. [CrossRef]

118. Zelber-Sagi, S.; Lotan, R.; Shlomai, A.; Webb, M.; Harrari, G.; Buch, A.; Nitzan Kaluski, D.; Halpern, Z.; Oren, R. Predictors for incidence and remission of NAFLD in the general population during a seven-year prospective follow-up. J. Hepatol. 2012, 56, 1145-1151. [CrossRef]

119. Verhaegh, P.; Bavalia, R.; Winkens, B.; Masclee, A.; Jonkers, D.; Koek, G. Noninvasive tests do not accurately differentiate nonalcoholic steatohepatitis from simple steatosis: A systematic review and meta-analysis. Clin. Gastroenterol. Hepatol. 2018, 16, 837-861. [CrossRef]

120. Aksoy, G.K.; Artan, R.; Aksoy, C.; Özdem, S.; Atalay, A.; Y1lmaz, A. Role of soluble adiponectin receptor 2 in non-alcoholic fatty liver disease in children. Pediatr. Gastroenterol. Hepatol. Nutr. 2019, 22, 470-478. [CrossRef]

121. Boyraz, M.; Cekmez, F.; Karaoglu, A.; Cinaz, P.; Durak, M.; Bideci, A. Serum adiponectin, leptin, resistin and RBP4 levels in obese and metabolic syndrome children with nonalcoholic fatty liver disease. Biomark. Med. 2013, 7, 737-745. [CrossRef] [PubMed] 
122. Shimada, M.; Kawahara, H.; Ozaki, K.; Fukura, M.; Yano, H.; Tsuchishima, M.; Tsutsumi, M.; Takase, S. Usefulness of a combined evaluation of the serum adiponectin level, HOMA-IR, and serum type IV collagen 7S level to predict the early stage of nonalcoholic steatohepatitis. Am. J. Gastroenterol. 2007, 102, 1931-1938. [CrossRef]

123. Da Silva, T.E.; Costa-Silva, M.; Correa, C.G.; Denardin, G.; Ayres Alencar, M.L.; Pacheco Honorico Coelho, M.S.; Muraro-Wildner, L.; Luiza-Bazzo, M.; González-Chica, D.A.; Dantas-Correa, E.B.; et al. Clinical significance of serum adiponectin and resistin levels in liver cirrhosis. Ann. Hepatol. 2018, 17, 286-299. [CrossRef] [PubMed]

124. Salman, T.A.; Allam, N.; Azab, G.I.; Shaarawy, A.A.; Hassouna, M.M.; El-Haddad, O.M. Study of adiponectin in chronic liver disease and cholestasis. Hepatol. Int. 2010, 4, 767-774. [CrossRef] [PubMed]

125. Siegel, A.B.; Goyal, A.; Salomao, M.; Wang, S.; Lee, V.; Hsu, C.; Rodriguez, R.; Hershman, D.L.; Brown, R.S.; Neugut, A.I.; et al. Serum adiponectin is associated with worsened overall survival in a prospective cohort of hepatocellular carcinoma patients. Oncology 2015, 88, 57-68. [CrossRef] [PubMed]

126. Kalafateli, M.; Triantos, C.; Tsochatzis, E.; Michalaki, M.; Koutroumpakis, E.; Thomopoulos, K.; Kyriazopoulou, V.; Jelastopulu, E.; Burroughs, A.; Lambropoulou-Karatza, C.; et al. Adipokines levels are associated with the severity of liver disease in patients with alcoholic cirrhosis. World J. Gastroenterol. 2015, 21, 3020-3029. [CrossRef]

127. Nkontchou, G.; Bastard, J.P.; Ziol, M.; Aout, M.; Cosson, E.; Ganne-Carrie, N.; Grando-Lemaire, V.; Roulot, D.; Capeau, J.; Trinchet, J.C.; et al. Insulin resistance, serum leptin, and adiponectin levels and outcomes of viral hepatitis C cirrhosis. J. Hepatol. 2010, 53, 827-833. [CrossRef]

128. Hamdy, K.; Al Swaff, R.; Hussein, H.A.; Gamal, M. Assessment of serum adiponectin in Egyptian patients with HCV-related cirrhosis and hepatocellular carcinoma. J. Endocrinol. Invest. 2015, 38, 1225-1231. [CrossRef]

129. Buechler, C.; Wanninger, J.; Neumeier, M. Adiponectin, a key adipokine in obesity related liver diseases. World J. Gastroenterol. 2011, 17, 2801-2811. [CrossRef]

130. Wu, Z.J.; Cheng, Y.J.; Gu, W.J.; Aung, L.H. Adiponectin is associated with increased mortality in patients with already established cardiovascular disease: A systematic review and meta-analysis. Metabolism 2014, 63, 1157-1166. [CrossRef] 